OPEN ACCESS

Edited by:

Salem Chouaib,

Institut Gustave Roussy, France

Reviewed by: Alessandro Poggi,

Azienda Ospedaliera Universitaria

San Martino (IRCCS), Italy

Francois Ghiringhelli, INSERM, France

*Correspondence:

Robson Coutinho-Silva rcsilva@biof.ufri.br;

Luiz Eduardo Baggio Savio savio@biof.ufrj.br,

edubsavio@gmail.com

Specialty section:

This article was submitted to

Cancer Immunity and Immunotherapy,

a section of the journal

Frontiers in Immunology

Received: 16 September 2017

Accepted: 27 October 2017

Published: 14 November 2017

Citation:

de Andrade Mello P, Coutinho-Silva R and Savio LEB (2017) Multifaceted Effects of Extracellular Adenosine Triphosphate and Adenosine in the

Tumor-Host Interaction and

Therapeutic Perspectives.

Front. Immunol. 8:1526. doi: 10.3389/fimmu.2017.01526

\section{Multifaceted Effects of Extracellular Adenosine Triphosphate and Adenosine in the Tumor-Host Interaction and Therapeutic Perspectives}

\author{
Paola de Andrade Mello', Robson Coutinho-Silva ${ }^{2 *}$ and Luiz Eduardo Baggio Savio ${ }^{2 *}$ \\ 'Division of Gastroenterology, Department of Medicine, Beth Israel Deaconess Medical Center, Harvard Medical School, \\ Boston, MA, United States, 2Instituto de Biofísica Carlos Chagas Filho, Universidade Federal do Rio de Janeiro, Rio de \\ Janeiro, Brazil
}

Cancer is still one of the world's most pressing health-care challenges, leading to a high number of deaths worldwide. Immunotherapy is a new developing therapy that boosts patient's immune system to fight cancer by modifying tumor-immune cells interaction in the tumor microenvironment (TME). Extracellular adenosine triphosphate (eATP) and adenosine (Ado) are signaling molecules released in the TME that act as modulators of both immune and tumor cell responses. Extracellular adenosine triphosphate and Ado activate purinergic type 2 (P2) and type 1 (P1) receptors, respectively, triggering the so-called purinergic signaling. The concentration of eATP and Ado within the TME is tightly controlled by several cell-surface ectonucleotidases, such as CD39 and CD73, the major ecto-enzymes expressed in cancer cells, immune cells, stromal cells, and vasculature, being CD73 also expressed on tumor-associated fibroblasts. Once accumulated in the TME, eATP boosts antitumor immune response, while Ado attenuates or suppresses immunity against the tumor. In addition, both molecules can mediate growth stimulation or inhibition of the tumor, depending on the specific receptor activated. Therefore, purinergic signaling is able to modulate both tumor and immune cells behavior and, consequently, the tumor-host interaction and disease progression. In this review, we discuss the role of purinergic signaling in the host-tumor interaction detailing the multifaceted effects of EATP and Ado in the inflammatory TME. Moreover, we present recent findings into the application of purinergic-targeting therapy as a potential novel option to boost antitumor immune responses in cancer.

Keywords: purinergic signaling, $\mathrm{P} 2 \mathrm{X} 7$ receptor, CD39, CD73, tumor microenvironment, immunotherapy

\section{INTRODUCTION}

Cancer is still one of the world's most pressing health-care challenges, leading to death in an estimated number of 600,920 patients per year in the United States (1). However, recent advances in cancer immunotherapy have transformed the treatment of several patients, extending and improving their lives $(2,3)$. Immunotherapy is a new developing therapy that boosts patient's immune system 
to fight cancer, by modifying tumor-immune cells interaction in the tumor microenvironment (TME) (4). According to the cancer immunoediting concept, the interaction between cancer and immune cells occurs in three essential phases: elimination, equilibrium, and escape-from cancer immune surveillance to immune escape (5-7). In the elimination and equilibrium phase innate and adaptive immune system-mainly NK and T cells-mount an effective immune response against the highly immunogenic tumors, and allow the less immunogenic ones escape (8-16). This immunologic pressure selects and favors tumor variants resistant to the immune system to proliferate (immunoevasion) $(9,17)$. During this process, both cancer and inflammatory cells release several soluble factors such as cytokines, chemokines, growth factors, matrix-degrading enzymes, and nucleotides that facilitate tumor immune escape and allow tumor growth, angiogenesis, invasion, and metastasis (18-22). Therefore, targeting multiple molecules that avoid immunoevasion and boost antitumor immune responses are the leading paths to successfully treat a whole range of tumor types (3).

Among the nucleotides released in the TME, extracellular adenosine triphosphate (eATP) and adenosine (Ado) are potent modulators of both immune and tumor cell response $(23,24)$. eATP and Ado exert their effects acting through P2 and P1 purinergic receptors, respectively, triggering the so-called purinergic signaling $(25,26)$. Purinergic signaling has long been involved with inflammation and cancer having a pivotal role in modulating cell migration, proliferation, and cell death $(27,28) . P 2$ and P1 receptors are expressed by nearly all cell types (immune and non-immune cells) and differently trigger cell signaling according to their subtypes (29-31). The P2 receptor is subdivided into two separate subfamilies, P2X (P2X1-7) ionotropic ion channels receptors and P2Y (P2Y1, P2Y2, P2Y4, P2Y6, and P2Y11-P2Y14) G-protein-coupled receptors $(25,26)$, whereas the $P 1$ receptor family $\left(A_{1}, A_{2 A}, A_{2 B}\right.$, and $\left.A_{3}\right)$ only comprised by $\mathrm{G}$-protein-coupled receptors subtype (32). These different purinergic receptors express distinct agonist affinity and specificity, therefore influencing both tumor and immune cells behavior according to the levels of eATP/Ado in TME (33-35).

Levels of eATP and Ado are tightly controlled by several ectonucleotidases. Among them, CD39 and CD73 are the most important ecto-enzymes expressed in cancer cells, regulatory immune cells and vasculature responsible for modulating purinergic signaling within the TME $(36,37)$. CD39 is a member of the ectonucleoside triphosphate diphosphohydrolase (E-NTPDase) family that comprised of eight members (E-NTPDase1-8), each one with a distinct cellular location and catalytic properties (36, 37). E-NTPDase1 (CD39), E-NTPDase2, E-NTPDase3, and E-NTPDase 8 are plasma membrane-bound enzymes that degrade with different affinities adenosine triphosphate (ATP) and $\operatorname{ADP}$ to $\operatorname{AMP}(24,36,37)$. AMP is in turn converted to Ado by CD73, which is an ecto-5' -nucleotidase cell-surface enzyme (37). This sequential activity of CD39/CD73 is the main pathway for the eATP scavenging and generation of Ado in the tumor interstitium $(24,36)$.

Once accumulated in the TME, eATP and Ado act as signaling molecules triggering different and opposite effects on both host and tumor cells. While eATP boosts antitumor immune response and Ado attenuates or suppresses immunity on the host side (38-45), both molecules can mediate growth stimulation or inhibition on the tumor cells, depending on the specific receptor activated (46-52). Regardless, the final effect on tumor growtheither beneficial or detrimental-will depend on the eATP/Ado levels, the panel of $\mathrm{P} 2$ and $\mathrm{P} 1$ receptors subtypes and CD39/CD73 expression by immune, tumor, and stromal cells in the TME (22).

Therefore, despite its complexity and dual behavior, modulation of purinergic signaling by targeting eATP/Ado pathways appears to be a promising strategy to modify cancer and immune cells cross talk in the TME $(24,36,53)$. In this review, we will discuss the role of purinergic signaling into the host-tumor interaction detailing the multifaceted effects of eATP and Ado in the inflammatory TME. Furthermore, we will highlight the application of combining purinergic-targeting therapies with other anticancer treatments as a potential new strategy to overcome immune escape, potentiate antitumor immune response, and, consequently, restrain tumor growth.

\section{eATP IN THE TME}

Measurement of eATP levels in different biological context reveals that healthy tissues present very low levels (10-100 nM) of this nucleotide in the pericellular space, while in sites of tissue damage, inflammation, hypoxia, ischemia, TME or metastases it can reach high levels (hundreds of micromoles per liter) $(24,54-56)$. ATP is abundantly released in the extracellular space due to cell death, cell stress, and activation of pannexin/ connexin channels on immune and endothelial cells $(54,57,58)$. In these settings, increased levels of eATP are sensed as a "danger signal" by the innate immune cells resulting in their recruitment to the damaged-tissue site $(42,57,59-61)$. Particularly in the TME, eATP acting through P2 receptors boosts the antitumor immunity at the same time that stimulates endothelial and tumor cells $(27,36,42,48,60)$.

\section{eATP Effect on the Host Side}

Activation of P2 receptors by eATP shapes various innate and adaptive immune responses (30). The $\mathrm{P} 2 \mathrm{X}$ and $\mathrm{P} 2 \mathrm{Y}$ receptors expression (either constitutive or upregulated in pathological conditions) varies according to the cell type and therefore dictates immune cell function, such as metabolism, adhesion, activation, migration, maturation, release of inflammatory mediators, cytotoxicity, and cell death, as extensively reviewed in Ref. $(30,36,62)$. In the innate immunity, activation of $\mathrm{P}_{2} \mathrm{Y}_{2}$ and $\mathrm{P} 2 \mathrm{X} 7$ receptors leads to stimulation of myeloid cells and promotes chemotaxis of macrophages and neutrophils $(38,63-65)$. At the same time, engagement of $\mathrm{P} 2 \mathrm{Y}_{2}$ and $\mathrm{P} 2 \mathrm{X} 7$ receptors induces dendritic cells (DCs) activation and chemotaxis (66). Indeed, stimulation of P2Y ${ }_{11}$ receptor inhibits IL-12 and boosts IL-10 release by DCs (67) whereas it activates granulocytes (68). In the adaptive immunity, engagement of various $\mathrm{P} 2 \mathrm{X}$ receptors, such as $\mathrm{P} 2 \mathrm{X} 1, \mathrm{P} 2 \mathrm{X} 4, \mathrm{P} 2 \mathrm{X} 5$, and $\mathrm{P} 2 \mathrm{X} 7$, results in T-cell activation $(39,69-71)$. Among them, $\mathrm{P} 2 \mathrm{X} 7$ has been linked to stimulation of $\mathrm{CD} 4^{+}$and $\mathrm{CD} 8^{+}$effector T cells $(40,69,72)$ as well as NKT cells $(73)$, induction of Treg apoptosis $(41,74,75)$, and inhibition of $\operatorname{Tr} 1$ cell differentiation (76). In addition, ATP acting via the P2X7 receptor is crucial to 
the generation of inflammatory Th17 lymphocytes by contributing for the generation of a microenvironment with high levels of IL-1 $\beta$, IL-6, and IL-17 $(77,78)$.

In the context of TME, recent studies have highlighted the importance of eATP acting through the P2X7 receptor in the chemotherapy-elicited anticancer immune response, also known as immunogenic cell death (ICD) $(42,60)$. Accordingly, ATP derived from dying tumor cells stimulates $\mathrm{P} 2 \mathrm{X} 7$ receptors in DCs, thus activating the NLRP3/ASC/caspase-1 inflammasome and driving the secretion of interleukin- $1 \beta$ (IL-1 $\beta$ ). IL- $1 \beta$ is then required for the adequate polarization of IFN $\gamma$-producing $\mathrm{CD}^{+}$ T cells, which is critical for the efficacy of chemotherapy $(42,60)$.

Despite its role in ICD, eATP-P2X7 signaling has also been related to the control of tumor growth. Recent studies have shown that host P2X7 expression limits tumor growth and metastasis spread by supporting an antitumor immune response $(47,79)$. Host P2X7 seems to boosts cytokine release, chemotaxis, and tumor infiltration by inflammatory cells. Accordingly, P2X7 host genetic deletion in mouse (P2X7-KO) impaired immune response against melanoma (B16) and colon carcinoma cells (CT26), leading to accelerate tumor growth in comparison to P2X7-WT hosts. Moreover, transplantation of P2X7-WT bone marrow to $\mathrm{P} 2 \mathrm{X} 7-\mathrm{KO}$ mice reduced tumor growth at a rate similar to the P2X7-WT group (47).

Even though eATP acting through P2X7 receptor seems to be an important signaling to stimulate immune cell response against the tumor, a critical role for the ATP/P2X7 receptor axis in modulating myeloid-derived suppressor cells (MDSCs) functions in the TME has also been described (23). Accordingly, P2X7 receptor activation stimulates the release of reactive oxygen species, arginase- 1 , and transforming growth factor- $\beta 1$ (TGF- $\beta 1$ ) from monocyte MDSCs present in the TME, contributing to MDSC immunosuppressive effect. Therefore, considering these contradictory effects the use of both antagonist/agonist of the P2X7 receptor has been investigated as a promising novel strategy for anticancer therapy and will be discussed with more details below.

\section{eATP Effect on the Tumor Side}

Practically all types of cancer cells express $\mathrm{P} 2 \mathrm{X}$ and $\mathrm{P} 2 \mathrm{Y}$ receptors that efficiently sense changes in ATP concentration in the TME and modulate different cellular functions such as proliferation, differentiation, and apoptosis $(24,28)$. Cancer cells may be more sensitive to the cytotoxic or to the trophic effect of e ATP according to the expression of their $\mathrm{P} 2$ receptor subtypes as well reviewed in Ref. (28).

Among the $\mathrm{P} 2 \mathrm{Y}$ receptors, stimulation of $\mathrm{P} 2 \mathrm{Y}_{2}$ and $\mathrm{P} 2 \mathrm{Y}_{11}$ receptors leads to cell proliferation and migration of human hepatocellular carcinoma (HCC) cells $(49,80)$. $\mathrm{P}_{2} \mathrm{Y}_{2}$ receptor activation is also highly involved with tumor invasiveness and metastatic diffusion in prostate and breast cancer (81-87). On the other hand, eATP-P2Y $\mathrm{Y}_{2}$ receptor signaling inhibited nasopharyngeal carcinoma and human colon carcinoma growth $(50,88)$. $\mathrm{P}_{2} \mathrm{Y}_{1}$ receptor activation induces apoptosis and inhibits human intestinal epithelial carcinoma, prostate cancer, and melanoma cell proliferation (89-91).

In the $\mathrm{P} 2 \mathrm{X}$ receptors family, a role for $\mathrm{P} 2 \mathrm{X} 3, \mathrm{P} 2 \mathrm{X} 5$, and $\mathrm{P} 2 \mathrm{X} 7$ in carcinogenesis has already been depicted, with a major focus on the $\mathrm{P} 2 \mathrm{X} 7$ receptor. $\mathrm{P} 2 \mathrm{X} 3$ receptor overexpression seems to be crucial for HCC cell survival and basal proliferation as well as proliferation in response to changes in ATP concentrations in the TME (92). Moreover, high P2X3 receptor expression is associated with poor prognosis in patients with HCC. P2X5 overexpression was also demonstrated in human basal cell and squamous carcinomas, but differently, it was expressed exclusively on cells undergoing proliferation and differentiation, suggesting a different role in tumor growth (93).

$\mathrm{P} 2 \mathrm{X} 7$ is far the most $\mathrm{P} 2 \mathrm{X}$ receptor subtype studied in cancer. Unlike the other $\mathrm{P} 2$ receptors, $\mathrm{P} 2 \mathrm{X} 7$ is unique for its capacity to form a nonselective pore on the plasma membrane upon stimulation with high levels of eATP, leading to cell death $(94,95)$. Its role in carcinogenesis remains a controversy, but now it is known that $\mathrm{P} 2 \mathrm{X} 7$ receptor triggers cell death or growth according to its level of activation and cell type stimulated (94, 96-98). As mentioned earlier, P2X7 receptor overstimulation with a high level of exogenous eATP triggers tumor cell death, while its tonic stimulation with endogenous eATP often induces cancer cell survival and proliferation $(28,99,100)$. Whereas the former leads to a marked mitochondrial catastrophe, the latter stabilizes the mitochondrial network, increases mitochondrial potential, oxidative phosphorylation, and aerobic glycolysis, culminating in a large increase in the overall intracellular ATP content and gain in proliferative advantage by P2X7-expressing cells (99). P2X7 receptor activation also triggers NFATc1, Erk, PI3K/Akt, and HIF-1 $\alpha$ intracellular pathways (101-103), being the PI3K/Akt pathway linked to the P2X7-dependent tumor cell growth, invasiveness, metastatic spreading, and angiogenesis $(101,104)$. Also supporting a role for P2X7 receptor in tumor growth is the fact that many types of cancer such as leukemia $(98,105,106)$, melanoma (107), neuroblastoma (108), pancreatic adenocarcinoma (109), esophageal carcinoma (110), breast (111), prostate (112), thyroid (113), and head and neck cancer (114) showed an increased expression of $\mathrm{P} 2 \mathrm{X} 7$ receptor. Moreover, in vivo experiments demonstrated that blocking P2X7 receptor activation by either silencing or a pharmacological manipulation decreased tumor progression and inhibited metastatic diffusion $(100,115)$. Therefore, it seems reasonable to say that $\mathrm{P} 2 \mathrm{X} 7$ receptor is an important target in cancer therapy not only for its role in the immune system but also for its impact on tumor growth. An overview of eATP effect on tumor and host side is illustrated in Figure 1.

\section{eADENOSINE IN THE TME}

High levels of extracellular adenosine (eAdo) were also demonstrated in the TME. While Ado levels in healthy tissue are around the nanomolar range, it can reach the micromolar range in the tumor core $(36,51,116,117)$. In the later context, many factors can contribute to Ado production, but hypoxia seems to be the main driver for the eAdo accumulation (118). In this setting, eAdo is mainly generated at the expenses of the eATP metabolism via the sequential enzymatic activity of CD39 and CD73 (119-122). CD39 catalyzes the first enzymatic reaction by breaking down ATP and ADP into AMP, whereas CD73 hydrolyzes AMP into Ado. CD73 irreversibly converts AMP to Ado being considered the rate-limiting enzyme for Ado formation $(37,122)$. 


\section{Extracellular ATP}

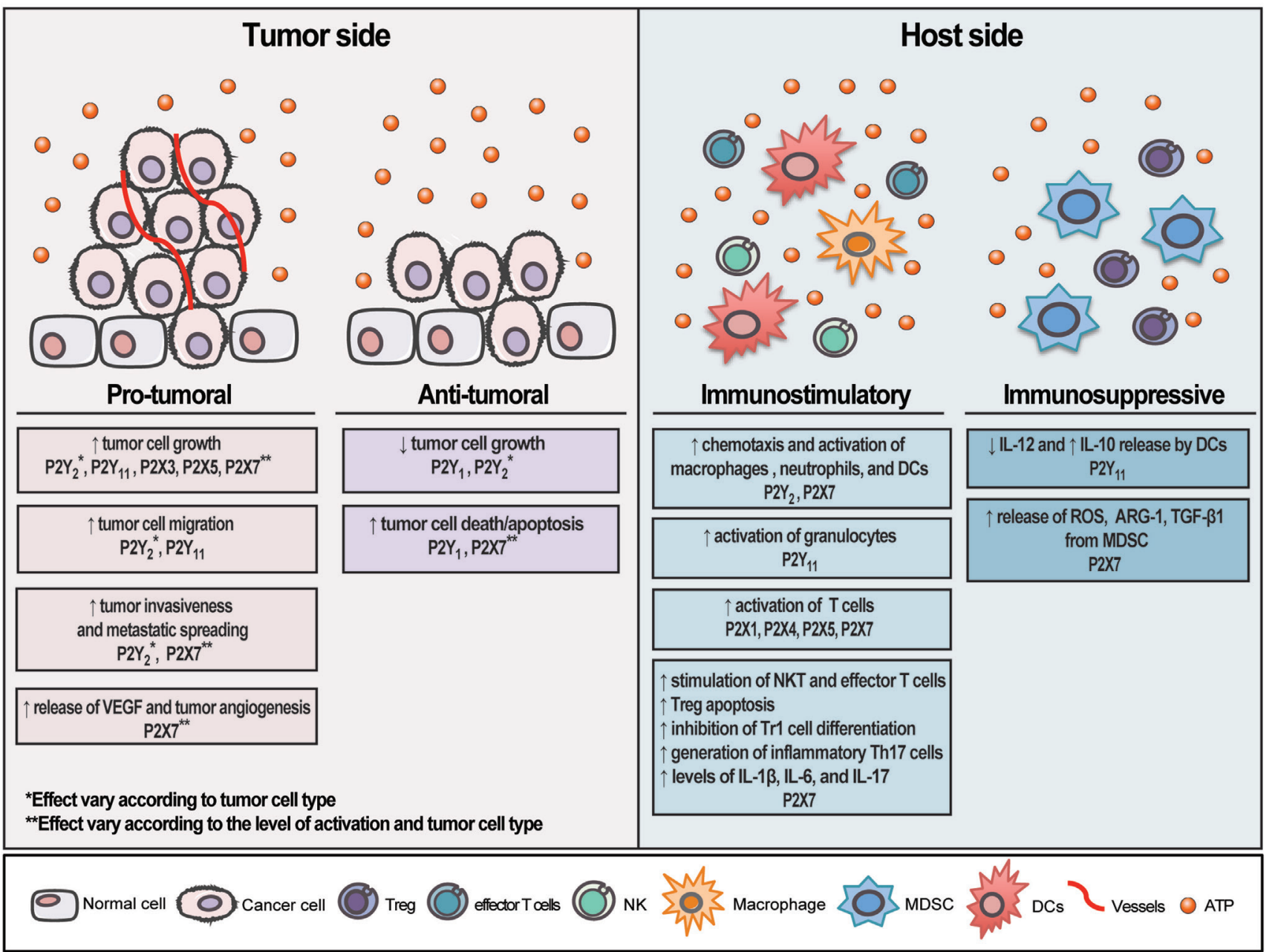

FIGURE 1 | Schematic illustration showing extracellular adenosine triphosphate (eATP) contrasting effects on tumor and host side. eATP can trigger different and opposite effects on both tumor and host cells depending on the cell type and receptor activated. The final result-either stimulating or restraining tumor growth-will depend on the eATP levels, the panel of P2 receptor subtypes and CD39/CD73 expression by tumor and immune cells present in the tumor microenvironment. Overall, eATP is a potent pro-inflammatory mediator, mostly boosting immune cells response.

Many cells have the capacity to generate eAdo in the TME, such as tumor cells $(43,120,123-126)$, Tregs $(120,127,128)$, Th17 (129, 130), MDSCs (44, 131, 132), endothelial cells (127, $133,134)$, cancer-associated fibroblast $(135,136)$, and mesenchymal stromal/stem cells (MSCs) $(45,137)$. Exosomes derived from CD $39^{+} \mathrm{CD}_{3}{ }^{+}$tumor cells (138), Tregs (139), or MSCs (45) can also contribute to eAdo production. Once in the pericellular space, Ado can exert a local signaling effect through the activation of the $\mathrm{P} 1$ purinergic receptors, be metabolized to inosine or recaptured by the cell via nucleoside transporters (140).

Likewise eATP, eAdo acts as an endogenous immunomodulatory molecule, but unlike the former, it mostly mediates immunosuppressive effects (30). Particularly in the tumor interstitium, eAdo acting through $\mathrm{P} 1$ receptors downregulates cell-mediated immunity at the same time that stimulates tumor cells and promotes angiogenesis $(45,133,136,137)$.

\section{eAdo Effect on the Host Side}

Extracellular adenosine exerts immunosuppressive activities in various immune subsets, interfering with antitumor immune responses (36). Innate and adaptive immune cells react to Ado stimulation according to the expression/density of the four P1 receptor subtypes, namely $A_{1}, A_{2 A}, A_{2 B}$, and $A_{3}(30,32)$. These receptors sense different levels of Ado and are classified as high-affinity $\left(A_{1}, A_{2 A}\right.$, and $\left.A_{3}\right)$ and low-affinity receptors $\left(\mathrm{A}_{2 \mathrm{~B}}\right)(32) . \mathrm{A}_{1}$ and $\mathrm{A}_{3}$ are $\mathrm{Gi}$-coupled receptors that inhibit adenylate cyclase and cyclic $A M P$ production, while $A_{2 A}$ and $\mathrm{A}_{2 \mathrm{~B}}$ are Gs-coupled receptors that stimulate cAMP synthesis and downstream signaling pathways $(32,141)$.

Activation of $\mathrm{A}_{2 \mathrm{~A}}$ and $\mathrm{A}_{2 \mathrm{~B}}$ receptors protect tissues against excessive immune reaction and therefore play a major role in Ado immunosuppressive effects (142-146). Stimulation of $\mathrm{A}_{2 \mathrm{~A}}$ receptor is related to the inhibition of DC activation (147), Th1/ Th2 cytokine production $(148,149), \mathrm{T}$ cells proliferation and 
activation $(148,149)$, and NK cells activation, maturation, and cytotoxicity $(125,150)$, as well as enhancement of the suppressive function of Tregs, Tr1 cells, and macrophages (151-153). In addition, $\mathrm{A}_{2 \mathrm{~A}}$ receptor activation prevents the LPS-induced increase in ectonucleotidase activities during inflammation $(154,155)$.

Activation of the $A_{2 B}$ receptor has a major effect on Tregs and MDSCs, stimulating Treg proliferation or differentiation from naïve T cells, production of IL-10 (156) and enhancing the suppressive function of MDSCs (44). $\mathrm{A}_{2 \mathrm{~B}}$ signaling is also linked to vascular endothelial growth factor (VEGF) secretion and tumor angiogenesis $(44,157)$. Engagement of $A_{2 A}$ and $A_{2 B}$ receptors inhibits neutrophils activation (158) and immune cells adhesion to endothelial cells (127). On the other hand, activation of $A_{1}$ and $A_{3}$ receptors promotes neutrophils chemotaxis and stimulates pro-inflammatory activities (158).

In general, Ado accumulation in the TME and its immunosuppressive effect via $\mathrm{A}_{2 \mathrm{~A}}$ and $\mathrm{A}_{2 \mathrm{~B}}$ receptors is a critical regulatory mechanism implemented by the tumors to evade the immunemediated cancer cells destruction, allowing tumor growth and impairing cancer immunosurveillance (159). In this way, new strategies targeting Ado production and signaling have emerged as a promising approach in cancer immunotherapy and will be discussed in more details below.

\section{eAdo Effect on the Tumor Side}

Differently from its effect on the host side, where Ado is well known for its strong immunosuppressive activities, on the tumor side Ado can either stimulate or inhibit tumor growth, depending on the cell type and receptor expressed by the tumor bulk (160). Likewise, pro- and antitumoral effects coming from $A_{1}$, $A_{2 A}, A_{2 B}$, and $A_{3}$ activation have been described (160). $A_{1}$ receptor activation is related to stimulation of MDA-MB-468 breast carcinoma cells proliferation (161) and melanoma cells chemotaxis (162). On the other hand, it may inhibit LoVo colon (163), TM4 Sertoli-like (164), MOLT-4 leukemia, T47D, HS578T, and MCF-7 breast, and glioblastoma cancer cells proliferation (160). Ado- $\mathrm{A}_{1}$ signaling has also been reported to protect endometrial carcinoma invasion and metastasis, by promoting cortical actin polymerization, increasing cell-cell adhesion thus preserving epithelial integrity (165). In the same manner, activation of $A_{2 A}$ and $\mathrm{A}_{2 \mathrm{~B}}$ receptors leads to controversial scenarios depending on the cell type studied. $\mathrm{A}_{2 \mathrm{~A}}$ stimulation results in increased MCF-7 breast cancer proliferation (166), whereas it promotes A375 melanoma cell death (167). Activation of $A_{2 B}$ receptor inhibits ER-positive MDA-MB-231 breast cancer cell proliferation, while it boosts oral squamous cell carcinoma progression $(168,169)$. Stimulation of $\mathrm{A}_{2 \mathrm{~B}}$ receptor also leads to reduced cell-cell contact and increased cell scattering in breast, lung, and pancreatic cancer cell lines, suggesting a role for this receptor in tumor invasion and metastatic spreading (170). These conflicting results might reflect differences in the experimental settings where distinct tumor cell lines were exposed to diverse agonist/antagonist drugs with different specificity and selectivity. Moreover, the use of specific agonist might not reflect the real effect triggered by Ado in the context of the tumor bulk given the complexity and heterogeneity of cells, Ado receptors, and downstream signaling that interact to produce the final cellular response.
$\mathrm{A}_{3}$ is by far the most studied Ado receptor in cancer and conflicting results have also been reported for this receptor. $\mathrm{A}_{3}$ receptor is expressed by many tumor cell lines, such as HL60 and K562 human leukemia (171, 172), Jurkat lymphoma (173), U937 monocytic-macrophagic human cell lines $(174,175), \mathrm{Nb} 2$ rat lymphoma (176), A375 human melanoma (177), PGT-betamouse pineal gland tumor cells (178), human glioblastoma $(179,180)$, and human prostatic cancer cells (181). Moreover, $A_{3}$ overexpression (either protein or mRNA levels) has been reported in human melanoma, colon, breast, small-cell lung, thyroid, pancreatic, and HCC vs adjacent normal tissue, supporting the notion that $\mathrm{A}_{3}$ receptor levels may reflect the status of tumor progression (182-184). In accordance with this statement, $A_{3}$ activation increases HT29, DLD-1 and Caco- 2 colon cancer cell proliferation (160). However, $\mathrm{A}_{3}$ stimulation also results in antitumoral effects, inhibiting proliferation of Nb2-11C and YAC-1 lymphoma, K562 and HL60 leukemia, B16-F10 and A375 melanoma, LN-Cap and PC3 prostate carcinoma, MIA-PaCa pancreatic carcinoma, breast and Lewis lung carcinoma cells (176, 185-189). Contrasting responses were also reported for $\mathrm{A}_{3}$ stimulation on metastatic spreading, leading to either increased (HT29 colon carcinoma) or decreased (prostatic cancer) cell migration $(179,181)$. Despite these dual effects, the $\mathrm{A}_{3}$ receptor has been pointed as a potential target for tumor growth inhibition $(182,190)$. A phase I/II clinical trial using an $\mathrm{A}_{3}$ agonist for the treatment of advanced unresectable HCC has been performed and despite preliminary data, favorable results were demonstrated in patients (191).

Rather than acting through $\mathrm{P} 1$ receptors, eAdo can also promote tumor cell death via its continuous uptake into the cell (52). Our group demonstrated that Ado formed from eATP degradation is the main factor responsible for apoptosis induction in human cervical cancer cells. Accordingly, eAdo transported into the cell through the nucleoside transporters leads to AMPK activation, p53 increase, PARP cleavage, and autophagy induction, culminating in cell death (52). Similar results were also reported in human gastric cancer cells (192), malignant pleural mesothelioma cell (193), mouse neuroblastoma cells (194), astrocytoma cells (195), and human epithelial cancer cells originating from breast, ileum, colon, and ovary $(89,196)$, bringing a distinct insight into the Ado effect on the tumor side. An overview of eAdo effect on tumor and host side is illustrated in Figure 2.

\section{PURINERGIC SIGNALING AS POTENTIAL TARGET FOR CANCER THERAPY}

As depicted alongside this review, purinergic signaling has a major role in controlling tumor growth, survival, and progression, not only by acting on tumor cells but also by modulating the immune system and the interaction of tumor and immune cells in the TME (24). Therefore, many potential targets involving ATP and Ado signaling has emerged as attractive candidates for cancer therapy. In this topic, we will discuss recent findings in this field highlighting $\mathrm{P} 2 \mathrm{X} 7, \mathrm{CD} 39, \mathrm{CD} 73$, and $\mathrm{A}_{2 \mathrm{~A}}$ receptor targeting therapy to restrain tumor progression in vivo models and in patients. 


\section{Extracellular Adenosine}

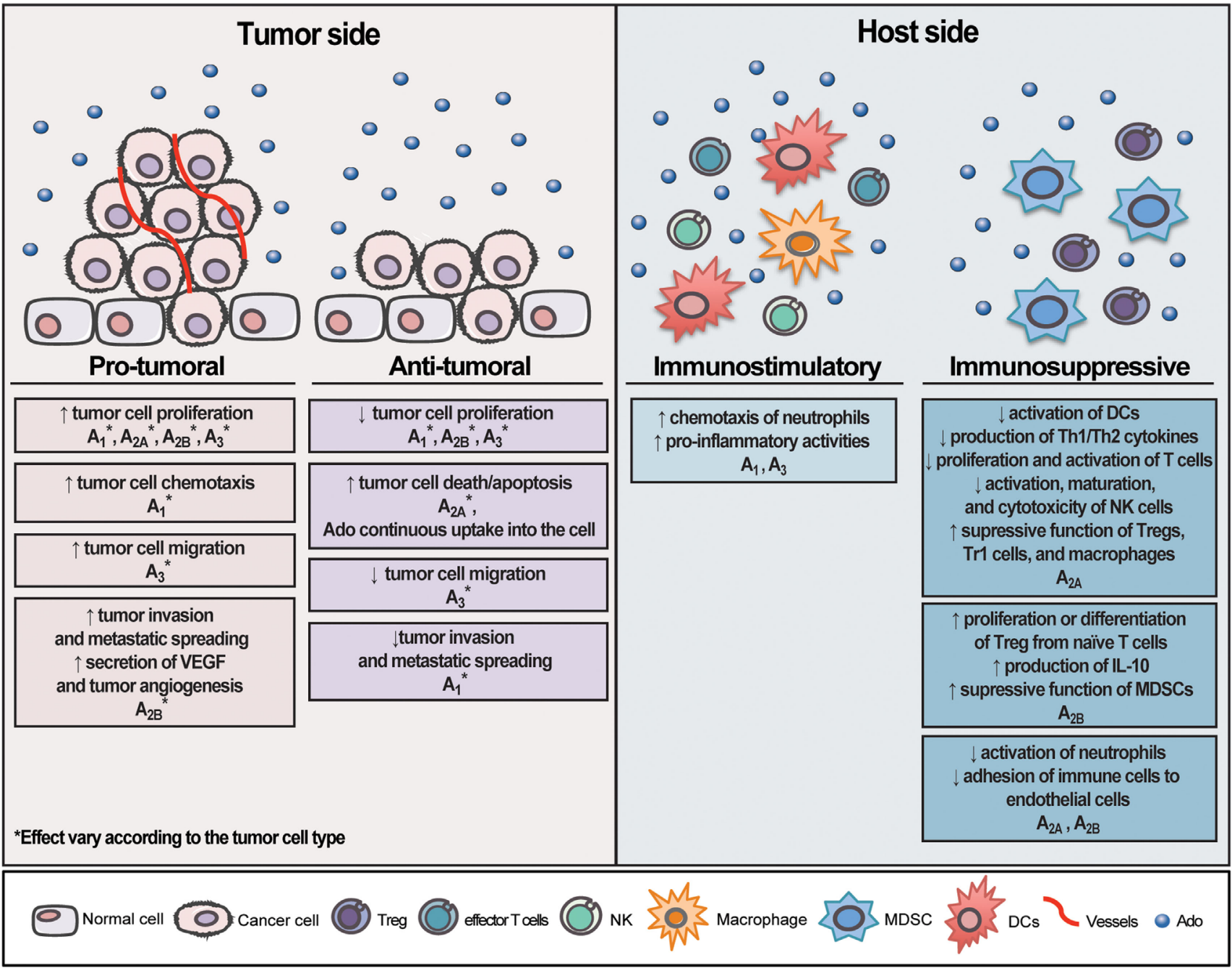

FIGURE 2 | Schematic illustration exhibiting extracellular adenosine (eAdo) opposing effects on tumor and host side. Likewise extracellular adenosine triphosphate (eATP), eAdo can exert distinct and contrasting effects on both tumor and host cells depending on the cell type and receptor activated. eAdo can also promote tumor cell death via its continuous uptake into the cell. As depicted by eATP, the sum of eAdo levels, the group of P1 receptor subtypes, and CD39/CD73 expression by tumor and immune cells in the tumor microenvironment will dictate the final effect on tumor growth. Overall, eAdo is a potent immunosuppressive nucleoside, mostly inhibiting immune cell responses.

\section{Targeting P2X7 Receptor in Cancer Therapy}

As discussed earlier, the $\mathrm{P} 2 \mathrm{X} 7$ receptor has contrasting effects when activated on the tumor or the host cells, potentiating or inhibiting tumor growth-depending on the level of stimulation-while boosting inflammation, respectively. Evidence supporting P2X7 growth-promoting activity has increased recently, and it appears to result from a large number of effects, i.e., inducing the release of immunosuppressive molecules by MDSCs and promoting VEGF release, angiogenesis, and tumor cell proliferation $(23,100)$. On the other hand, $\mathrm{P} 2 \mathrm{X} 7$ receptor seems to restrain tumor growth by promoting DC/cancer cell interaction, cytokine release, chemotaxis, and infiltration of immune cells in the TME (53). Therefore, both strategies either stimulating or blocking P2X7 receptor have been studied to hinder cancer growth $(46,197)$.

$\mathrm{P} 2 \mathrm{X} 7$ receptor overstimulation by using high levels of eATP was the first attempt to increase tumor cell death through its known apoptotic/necrotic function. Administration of very high levels of ATP (25 and $50 \mathrm{mM}$ ) effectively reduced the growth of hormone-refractory prostate cancer and melanoma tumors in vivo, respectively $(198,199)$. However, these studies were performed in nude athymic mice, therefore excluding a role for the immune system on this antitumor effect. eATP acting exclusively through $\mathrm{P} 2 \mathrm{X} 7$ receptor also inhibited colon carcinoma and melanoma tumor growth in C57BL/6 wild-type mice, by perturbing the balance between two signaling axes-P2X7-PI3K/AKT and P2X7-AMPK-PRAS40-mTOR-and promoting tumor cell 
death through autophagy (48). Again, this result was focused on the stimulation of the tumor $\mathrm{P} 2 \mathrm{X} 7$ receptor, and no mention to the host counterpart was reported. Regardless of these promising results, three clinical trials fail to demonstrate a beneficial impact by using exogenous ATP to treat cancer in patients, being an improvement of the quality of life the only positive effect demonstrated (200-202). Besides eATP, the use of P2X7 receptor agonists, such as BzATP and ATP $\gamma \mathrm{S}$, has also been employed to delay tumor growth, but once more, only the effect on the P2X7 receptor tumor side was evaluated $(203,204)$. Accordingly, BzATP inhibited the formation of DMBA/TPA-induced skin papillomas and carcinomas in wild-type FVB mice (203), while ATP $\gamma \mathrm{S}$ decreased the tumor growth and metastasis of mouse mammary carcinoma cells in wild-type C57BL/6 mice (204).

$\mathrm{P} 2 \mathrm{X} 7$ receptor activation through the eATP released from the irradiation and chemotherapy has also an important role in controlling tumor response to those treatments (205-207). In glioblastoma, P2X7 receptor expression by tumor cells dictated patient response to radiotherapy (208). Accordingly, high levels of $\mathrm{P} 2 \mathrm{X} 7$ receptor are associated with good prognosis and increased glioma radiosensitivity. Moreover, P2X7 silencing prevents tumor response to radiation in an in vivo model of glioblastoma, reinforcing that functional P2X7 expression is crucial for an efficient radiotherapy response (208). Likewise, eATP acting via P2X7 receptor on DCs is determinant for the chemotherapy-induced ICD, stimulating host-specific immune responses $(206,207)$. We recently showed the importance of $\mathrm{P} 2 \mathrm{X} 7$ receptor overactivation in colon cancer cells to potentiate chemotherapy cytotoxicity (209). According to our data, hyperthermia-by influencing plasma membrane fluidity-boosted P2X7 functional responses to eATP, leading to maximal tumor cell death, mainly in association with chemotherapy drugs. Therefore, P2X7 hyperactivation by hyperthermia might be used as an adjunct therapy in the treatment of cancer.

Tumor P2X7 receptor expression and activation and its impact on cancer proliferation have long been investigated. However, two recent studies also demonstrated a critical role for the host $\mathrm{P} 2 \mathrm{X} 7$ receptor in stimulating the antitumoral immune response and restraining the tumor growth $(47,79)$. Correspondingly, animals with host genetic deletion of P2X7 were not able to mount an effective host inflammatory response, reporting reduced cell infiltration at the tumor bed, accelerated tumor growth, and metastatic spreading in comparison to the wild-type group.

Although the overstimulation of $\mathrm{P} 2 \mathrm{X} 7$ receptor with agonists appears to be the most logical strategy to decrease tumor proliferation, by inducing both tumor cell death and antitumor immune response, recent studies have been demonstrated that blocking $\mathrm{P} 2 \mathrm{X} 7$ receptor activation is more efficacious in preventing tumor growth, mainly in those cancers in which $\mathrm{P} 2 \mathrm{X} 7$ receptor is overexpressed $(28,46,47,100)$. Administration of P2X7 inhibitors and antagonists has been shown to decrease cancer cell growth or spreading in animal models of colon (100), breast (115) and ovarian carcinoma (210), neuroblastoma (101), melanoma (47, 100), and glioma (211).

Several inhibitors and antagonists have been used to block P2X7 receptor in tumor cells, including oxidized-ATP (100, 212), BBG (210), AZ10606120 (47, 100, 101), A740003 (47, 101),
A438079 (115), and also P2X7 blocking antibodies (115). A recent phase I clinical trial using anti-P2X7 antibody to treat basal cell carcinoma demonstrated exciting results and showed that $65 \%$ of patients respond to the treatment and had a significant reduction on the lesion area (213). The authors support the use of antibodies against $\mathrm{P} 2 \mathrm{X} 7$ receptor as a safe and well tolerable treatment for BBC.

An important point to be considered is that the use of P2X7 receptor antagonists have been shown to demonstrate strong anticancer effects in immune-competent mice expressing P2X7 in both tumor and host side $(47,100)$, suggesting that blocking $\mathrm{P} 2 \mathrm{X} 7$ on the tumor side is critical to the final antitumor action, despite the mild immunosuppressive effect due to inhibition of the P2X7 on the host side (53). Regardless, more studies investigating the $\mathrm{P} 2 \mathrm{X} 7$ receptor function in host/tumor interactions, and their impact on tumor growth will indicate the feasibility of using P2X7 as a new target in cancer therapy.

\section{Blocking CD39 Activity-First Step to Inhibit Ado Formation and Restore Antitumor Immune Response}

The conversion of eATP to Ado, either in physiological or pathological conditions, is mainly coordinated by the sequential activity of CD39 and CD73. In the TME, those enzymes will affect tumor growth according to their ability to produce Ado and therefore trigger an immunosuppressive signaling $(24,37)$.

Increased expression of CD39 has been widely reported in several tumors, such as medulloblastoma (214), sarcoma (215), HCC (216), pancreatic cancer (217), colorectal cancer $(218,219)$, gastric cancer (216), and endometrial cancer (220); as well as in infiltrating immune cells $(216,221-224)$ and tumor endothelial cells $(216,225)$, influencing tumor growth, metastasis and angiogenesis. As an example, expression of CD39 by Tregs plays a permissive role in a mouse model of hepatic metastasis by inhibiting NK cell antitumor immunity and contributing to tumor immune escape (226).

Therefore, strategies to block CD39 activity and Ado generation has become a new approach to avoid Ado immunosuppressive effects and restores the antitumor responses (36). So far, few approaches targeting CD39 by using pharmacological inhibitors, genetic deletion or antibodies have been rendered promising results $(215,224,226,227)$. As reported in the literature, blocking CD39 activity by using the inhibitor ARL67156 partially overcomes $\mathrm{T}$ cell hyporesponsiveness in a subset of patient samples with follicular lymphoma (224). In the same line, CD39 blockage with both inhibitor (ARL67156) and antibody (OREG-103/ BY40) increased T cells and NK cell-mediate cytotoxicity against SK-MEL-5 melanoma cells (228). In an in vivo model, injection of POM1, a pharmacological CD39 inhibitor, was able to limit B16F10 melanoma and MCA 38 colonic tumor growth at the same rate as demonstrated in animals $\mathrm{CD}^{-1-}$ (226). Indeed, CD39 deletion inhibited metastatic melanoma and colonic growth in the liver as well as decreased tumor angiogenesis (226). Similarly, CD39 deletion abrogated B16-F10 melanoma and LLC lung carcinoma tumor growth, angiogenesis, and pulmonary metastases in mice (227). In another study, treatment with a specific 
anti-CD39 antibody significantly improved survival in a lethal metastatic patient-derived sarcoma model (215).

Altogether, these studies indicate that blocking Ado formation through targeting CD39 is a promising strategy in cancer therapy not only for boosting the antitumor immune response (immunotherapy) but also for blocking tumor angiogenesis (antiangiogenic therapy). However, future studies involving the use of anti-CD39 antibodies will provide supportive insights into the potential clinical application of CD39-targeting therapy in oncology (36).

\section{Inhibiting CD73 Activity-Second Step to Block Ado Formation and Improve Antitumor Immune Response}

CD73 is a $5^{\prime}$ ectonucleotidase enzyme that degrades extracellular AMP-derived from the ATP metabolism - to Ado (37). As mentioned earlier, the sequential enzymatic activity of CD39 and CD73 is the main pathway for the generation of Ado in the tumor interstitium. In this context, CD73-derived Ado exerts many immunosuppressive effects to attenuate antitumor immunity (122). Likewise CD39, CD73 is expressed by cancer cells, regulatory immune cells, and the vasculature, therefore affecting tumor growth, metastasis and angiogenesis (36).

Elevated CD73 expression has been reported in several types of human cancers such as glioma (229-231), head and neck (128), melanoma (232), thyroid (233), breast (234-238), pancreas (239), colon $(219,240)$, bladder $(241,242)$, ovarian (243), prostate (244), and leukemia (126), being positively correlated with poor prognosis. In addition to tumor-derived CD73, host CD73 also negatively regulates tumor immunity (245). Accordingly, both hematopoietic and nonhematopoietic expression of CD73 is important to promote tumor immune escape. For example, Tregs-derived CD73 contributed to their immunosuppressive effects (245), while enzymatic activity of CD73 on tumor-associated endothelial cells restricted T cells homing to tumors (127). Altogether, these data suggest that both tumor and host CD73 cooperatively protect tumors from the immune system response, favoring cancer growth and spreading. Supporting this assumption, studies performed with CD73-deficient mice showed that animals lacking CD73 have an increased antitumor immunity and are resistant to carcinogenesis (245-247). Therefore, targeting CD73 appears to be a useful therapeutic tool to treat cancer.

Many approaches using small molecules inhibitors such as ACPC and antibodies against CD73 have shown important antitumor and antimetastatic effects in various preclinical models of melanoma $(127,245,246,248)$, fibrosarcoma (247), breast (125, $134,235,249,250)$, prostate (247), and ovarian cancer (123). Those effects are mainly attributed to the immune-stimulating activity of CD73 blockage on host and tumor cells. However, a role for CD73 in controlling cancer cell proliferation independently of the immune system was also reported (251). Accordingly, CD73 gene-silencing in human tumor cells promoted cell-cycle arrest and apoptosis, decreasing cell growth rate in a xenograft tumor model.

Targeting CD73 has also been shown to suppress tumor angiogenesis $(133,134)$. Anti-CD73 therapy with monoclonal antibody significantly reduced tumor VEGF levels and abolished tumor angiogenesis in a mouse model of breast cancer (134). Accordingly, tumor-derived CD73 triggered VEGF production by tumor cells, while endothelial-derived CD73 promoted the formation and migration of capillary-like structures by endothelial cells, demonstrating that CD73 expression on tumor and host cells contribute to tumor angiogenesis.

A phase I clinical trial study is currently undergoing to test safety, tolerability, and antitumor activity of anti-CD73 mAb, MEDI9447, in cancer patients (NCT02503774) (Table 1). MEDI9447 is a selective, potent, and non-competitive inhibitor of CD73 that blocks both membrane-bound and soluble states of this enzyme (252). Preclinical data using mouse syngenic CT26 colon carcinoma tumor model showed that MEDI9447 inhibited tumor growth by promoting changes in both myeloid and lymphoid infiltrating leukocytes within the tumor interstitium (253). Among these changes, increasing number of $\mathrm{CD}^{+}$effector $\mathrm{T}$ cells and activated macrophages in the TME

TABLE 1 | Clinical trials currently underway that are testing the potential use of anti-CD73 mAb and $\mathrm{A}_{2 \mathrm{~A}}$ antagonists alone or in combination with other immunotherapies to treat cancer.

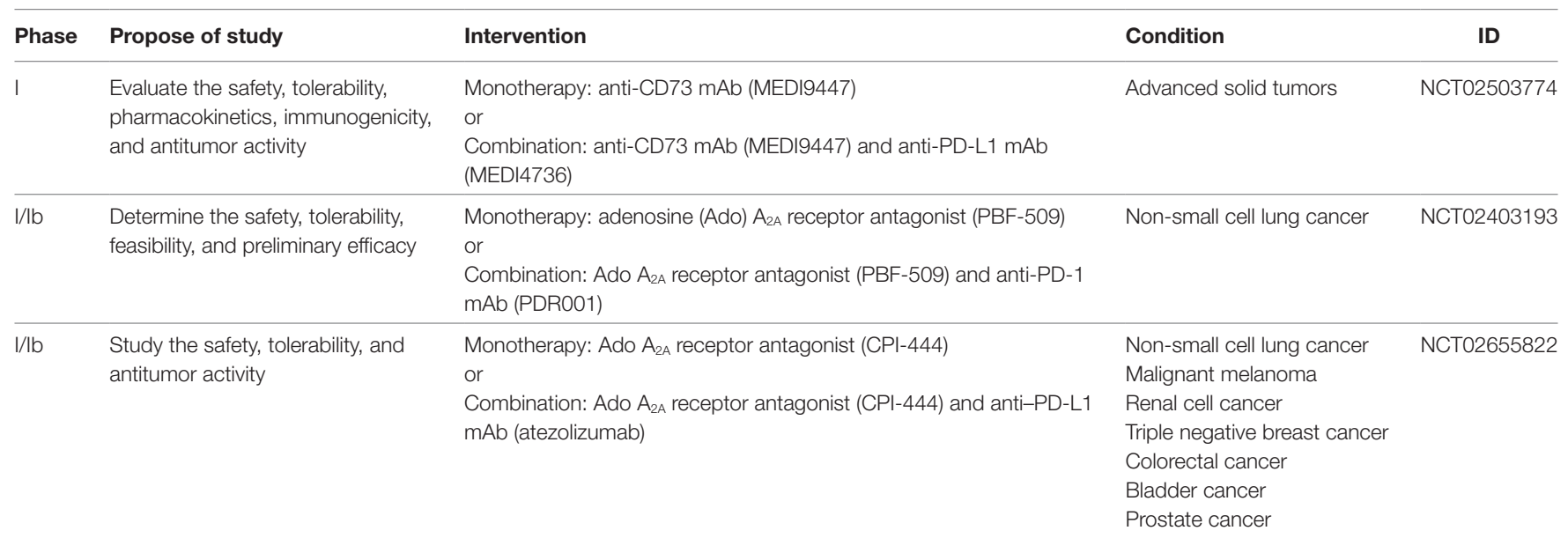


has been reported. In addition, mice treated with a combination of anti-CD73 and anti-programmed cell death protein (PD)-1 antibodies showed increased tumor rejection and survival rates when compared with mice treated with an individual antibody. Synergistic effects by combining CD73 blockade with other currently available anticancer agents, including anthracycline (254), radiation (160), anti-cytotoxic T-lymphocyte antigen (CTLA)-4 antibodies $(255,256)$, and anti-PD-1 antibodies (255) have also been reported and highlight the potential clinical application of CD73 target therapies in combination with other anticancer modalities to improve antitumor immune response as well as tumor death.

\section{Blocking $A_{2 A}$ Receptor-Alternative Approach to Restrain Ado Immunosuppressive Effect and Boost the Antitumor Immunity}

Targeting the Ado receptor $\mathrm{A}_{2 \mathrm{~A}}$ is also an alternative approach to block the Ado immunosuppressive effect and boost the antitumor immunity (36). As depicted earlier, $\mathrm{A}_{2 \mathrm{~A}}$ receptor plays an important role in triggering Ado immunosuppressive activities in many immune subsets. Therefore, blocking Ado $\mathrm{A}_{2 \mathrm{~A}}$ receptor with antagonist appears to be an attracting strategy, besides CD39 and CD73 inhibition, to increase innate and adaptive

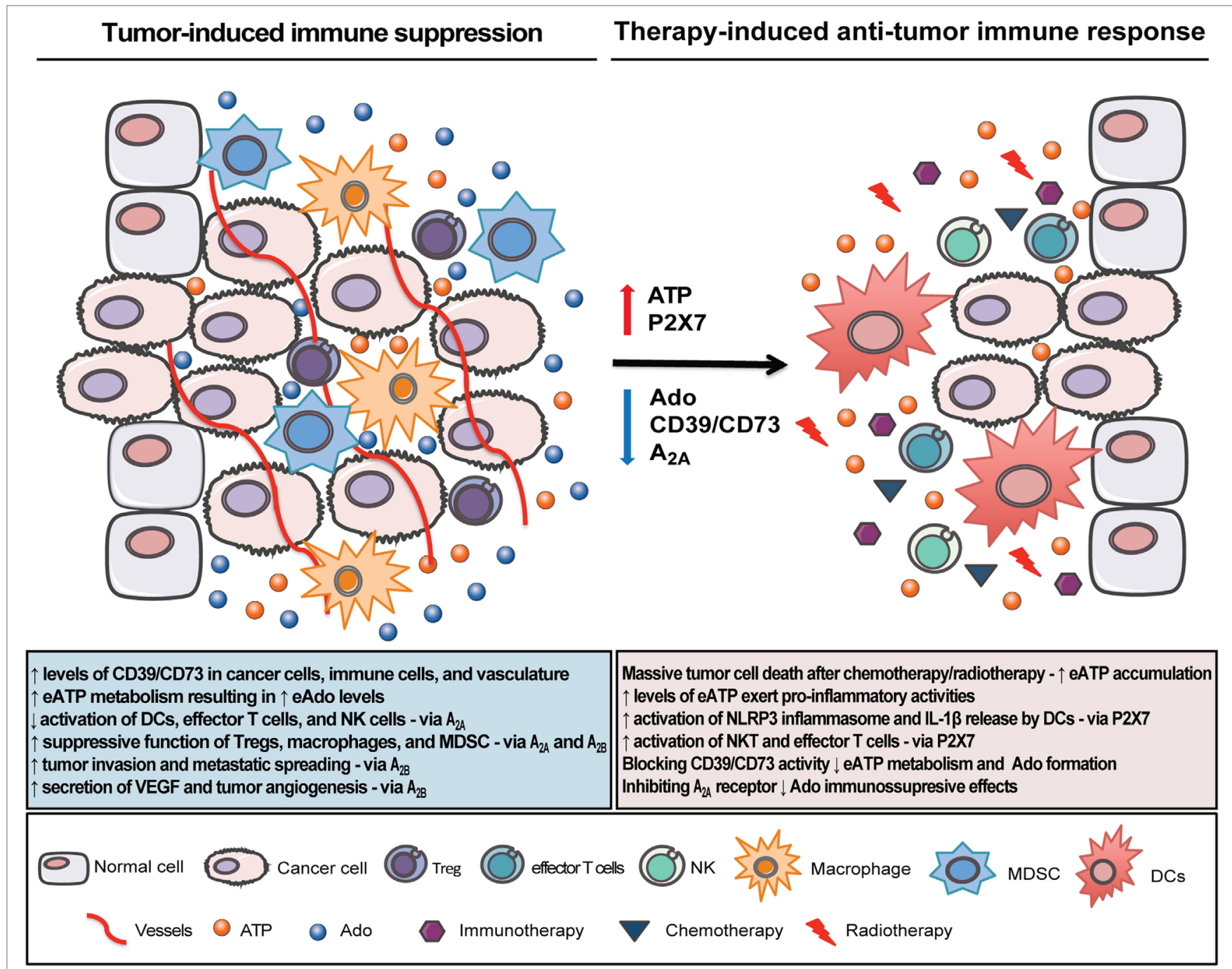

FIGURE 3 | Therapeutic strategies to overcome tumor immune escape and boost cancer immunosurveillance in the tumor microenvironment (TME). In the inflammatory TME, tumor and immune cells interact to produce a favorable immunosuppressive microenvironment. Extracellular adenosine triphosphate (eATP), a pro-inflammatory mediator, accumulates in the TME, but it is rapidly converted to the immunosuppressive factor adenosine (Ado) via the sequential enzymatic activity of CD39 and CD73. Ado acting through $A_{2 A}$ and $A_{2 B}$ receptors inhibits dendritic cells (DCs), NK, and effector T cells activation while it enhances the suppressive function of Tregs, macrophages, and myeloid-derived suppressor cell (MDSC). Strategies by targeting Ado formation, i.e., by blocking CD39/CD73 enzymes and Ado receptors (mainly $\mathrm{A}_{2 \mathrm{~A}}$ ) will build up eATP concentration and improve the antitumor immune response. Specifically on DCs, eATP acting through P2X7 receptor will trigger NLRP3 inflammasome activation and IL-1 $\beta$ release with consequent stimulation of CD8 ${ }^{+}$and CD4+ lymphocyte-mediated antitumor response, which is a critical step for the efficacy of chemotherapy and radiotherapy. Therefore, combining purinergic-targeting therapies with other anticancer modalities may be a new strategy to overcome immune escape, potentiate antitumor immune response, and consequently restrain tumor growth. 
immune response against the tumor (153). Many studies have been shown the potential use of $\mathrm{A}_{2 \mathrm{~A}}$ antagonists alone or in combination with other therapies to enhance antitumor immunity in preclinical models $(125,150,257,258)$. Combination therapies targeting both $\mathrm{A}_{2 \mathrm{~A}}$ receptor and co-inhibitory molecules, such as CTLA4 and PD-1, have shown synergistic effects (256, 257, 259). Coadministration of $A_{2 A}$ antagonist with anti-CTLA4 $\mathrm{mAb}$ marked inhibited tumor growth and enhanced antitumor immune responses in a mouse melanoma model (256). Moreover, dual blockade of $\mathrm{A}_{2 \mathrm{~A}}$ receptor and PD-1 significantly reduced $\mathrm{CD}_{7}{ }^{+}$tumor growth and metastasis spreading as well as prolonged mice survival $(257,259)$. The mechanism of the combination therapy was mainly dependent on NK cells, CD8 ${ }^{+}$ $\mathrm{T}$, cells and IFN- $\gamma$. Importantly, the overexpression of CD73 by tumor cells was critical for the efficacy of the combined therapy, suggesting that CD73 might be a potential biomarker for the selection of patients undergoing this method of treatment. Supporting this statement, co-inhibition of CD73 and $\mathrm{A}_{2 \mathrm{~A}}$ receptor by either gene deletion or pharmacological therapy limited tumor initiation, growth, and metastasis in vivo (260). In the double knockout (KO) mice, tumor control required $\mathrm{CD}^{+} \mathrm{T}$-cell and IFN- $\gamma$ production within the core of tumors, while therapeutic activity of CD73 antibodies depend on Fc receptors binding. Interestingly, $\mathrm{A}_{2 \mathrm{~A}}$ single $\mathrm{KO}$ mice showed a significant upregulation of CD73 expression in tumor cells and endothelial cells, suggesting that CD73 overexpression might be a mechanism of escape and resistance to monotherapy with $\mathrm{A}_{2 \mathrm{~A}}$ antagonists. So far, two clinical trials (phase I) are currently underway to evaluate safety, tolerability, and antitumor activity of $\mathrm{A}_{2 \mathrm{~A}}$ antagonists as a single agent and in combination with PD-1/PD-L1 inhibitors in patients (NCT02403193 and NCT02655822) (Table 1). Therefore, associating $\mathrm{A}_{2 \mathrm{~A}}$ antagonist with other checkpoint blockade inhibitors appears to be a promising strategy to improve patient survival and yet many

\section{REFERENCES}

1. Siegel RL, Miller KD, Jemal A. Cancer statistics, 2017. CA Cancer J Clin (2017) 67:7-30. doi:10.3322/caac.21387

2. Tsiatas M, Mountzios G, Curigliano G. Future perspectives in cancer immunotherapy. Ann Transl Med (2016) 4:273. doi:10.21037/atm.2016.07.14

3. Farkona S, Diamandis EP, Blasutig IM. Cancer immunotherapy: the beginning of the end of cancer? BMC Med (2016) 14:73. doi:10.1186/s12916016-0623-5

4. Stanculeanu DL, Daniela Z, Lazescu A, Bunghez R, Anghel R. Development of new immunotherapy treatments in different cancer types. JMed Life (2016) 9:240-8.

5. Mittal D, Gubin MM, Schreiber RD, Smyth MJ. New insights into cancer immunoediting and its three component phases - elimination, equilibrium and escape. Curr Opin Immunol (2014) 27:16-25. doi:10.1016/j. coi.2014.01.004

6. Teng MW, Galon J, Fridman WH, Smyth MJ. From mice to humans: developments in cancer immunoediting. J Clin Invest (2015) 125:3338-46. doi:10.1172/JCI80004

7. Schreiber RD, Old LJ, Smyth MJ.Cancer immunoediting: integrating immunity's roles in cancer suppression and promotion. Science (2011) 331:1565-70. doi:10.1126/science.1203486

8. Disis ML. Immune regulation of cancer. J Clin Oncol (2010) 28:4531-8. doi:10.1200/JCO.2009.27.2146 researchers have pointing the anti-adenosinergic signaling as the next-generation target in immuno-oncology.

\section{CONCLUSION}

Despite its complexity and contradictory effects, purinergic signaling has emerged as a novel targetable therapy to improve other anticancer modalities and cannot be underestimated considering its role in carcinogenesis. Strategies by blocking Ado formation and its immunosuppressive effects in the TME favoring eATP accumulation, and its pro-inflammatory effects appears to be the most promising approach to maximize the efficacy of other therapies such as immunotherapy, radiotherapy, and chemotherapy (Figure 3). However, considering the multifaceted effects of eATP and Ado in the TME, where host immune and stromal cells as well as tumor cells are modulated in different ways, choosing the most feasible purinergic target will be a challenging task. Ongoing and upcoming clinical trials will hopefully identify the best combinatorial approach to boost antitumor immune response and successfully restrain tumor growth.

\section{AUTHOR CONTRIBUTIONS}

PM, RC-S, and LS wrote the article. All the authors contributed to the study conception and design, and critically revised the manuscript.

\section{FUNDING}

This work was supported by funds from the Conselho Nacional de Desenvolvimento Cientifico e Tecnológico do Brasil (CNPq), Coordenação de Aperfeiçoamento de Pessoal de Nível Superior (CAPES), and Fundação de Amparo à Pesquisa do Estado do Rio de Janeiro (FAPERJ-Pós-doutorado Nota 10 Edital 05/2016).

9. Kim R, Emi M, Tanabe K. Cancer immunoediting from immune surveillance to immune escape. Immunology (2007) 121:1-14. doi:10.1111/ j.1365-2567.2007.02587.x

10. Dadi S, Chhangawala S, Whitlock BM, Franklin RA, Luo CT, Oh SA, et al. Cancer immunosurveillance by tissue-resident innate lymphoid cells and innate-like T cells. Cell (2016) 164:365-77. doi:10.1016/j.cell.2016.01.002

11. Chester C, Fritsch K, Kohrt HE. Natural killer cell immunomodulation: targeting activating, inhibitory, and co-stimulatory receptor signaling for cancer immunotherapy. Front Immunol (2015) 6:601. doi:10.3389/ fimmu.2015.00601

12. Naito Y, Saito K, Shiiba K, Ohuchi A, Saigenji K, Nagura H, et al. CD8+ $\mathrm{T}$ cells infiltrated within cancer cell nests as a prognostic factor in human colorectal cancer. Cancer Res (1998) 58:3491-4.

13. Yasunaga M, Tabira Y, Nakano K, Iida S, Ichimaru N, Nagamoto N, et al. Accelerated growth signals and low tumor-infiltrating lymphocyte levels predict poor outcome in T4 esophageal squamous cell carcinoma. Ann Thorac Surg (2000) 70:1634-40. doi:10.1016/S0003-4975(00)01915-9

14. Reichert TE, Day R, Wagner EM, Whiteside TL. Absent or low expression of the zeta chain in $\mathrm{T}$ cells at the tumor site correlates with poor survival in patients with oral carcinoma. Cancer Res (1998) 58:5344-7.

15. Sato E, Olson SH, Ahn J, Bundy B, Nishikawa H, Qian F, et al. Intraepithelial CD8+ tumor-infiltrating lymphocytes and a high CD8+/regulatory $\mathrm{T}$ cell ratio are associated with favorable prognosis in ovarian cancer. Proc Natl Acad Sci U S A (2005) 102:18538-43. doi:10.1073/pnas.0509182102 
16. Ishigami S, Natsugoe S, Tokuda $\mathrm{K}$, Nakajo A, Che $\mathrm{X}$, Iwashige $\mathrm{H}$, et al. Prognostic value of intratumoral natural killer cells in gastric carcinoma. Cancer (2000) 88:577-83. doi:10.1002/(SICI)1097-0142(20000201) 88:3<577::AID-CNCR13>3.0.CO;2-V

17. Singh SK, Dorak MT. Cancer immunoprevention and public health. Front Public Health (2017) 5:101. doi:10.3389/fpubh.2017.00101

18. Karnoub AE, Weinberg RA. Chemokine networks and breast cancer metastasis. Breast Dis (2006) 26:75-85. doi:10.3233/BD-2007-26107

19. Grivennikov SI, Greten FR, Karin M. Immunity, inflammation, and cancer. Cell (2010) 140:883-99. doi:10.1016/j.cell.2010.01.025

20. Qian BZ, Pollard JW. Macrophage diversity enhances tumor progression and metastasis. Cell (2010) 141:39-51. doi:10.1016/j.cell.2010.03.014

21. DeNardo DG, Andreu P, Coussens LM. Interactions between lymphocytes and myeloid cells regulate pro- versus anti-tumor immunity. Cancer Metastasis Rev (2010) 29:309-16. doi:10.1007/s10555-010-9223-6

22. Di VF. Purines, purinergic receptors, and cancer. Cancer Res (2012) 72:5441-7. doi:10.1158/0008-5472.CAN-12-1600

23. Bianchi G, Vuerich M, Pellegatti P, Marimpietri D, Emionite L, Marigo I, et al. ATP/P2X7 axis modulates myeloid-derived suppressor cell functions in neuroblastoma microenvironment. Cell Death Dis (2014) 5:e1135. doi:10.1038/ cddis. 2014.109

24. Di VF, Adinolfi E. Extracellular purines, purinergic receptors and tumor growth. Oncogene (2017) 36:293-303. doi:10.1038/onc.2016.206

25. Ralevic V, Burnstock G. Receptors for purines and pyrimidines. Pharmacol $\operatorname{Rev}(1998)$ 50:413-92.

26. Abbracchio MP, Burnstock G, Boeynaems JM, Barnard EA, Boyer JL, Kennedy C, et al. International union of pharmacology LVIII: update on the P2Y G protein-coupled nucleotide receptors: from molecular mechanisms and pathophysiology to therapy. Pharmacol Rev (2006) 58:281-341. doi:10.1124/pr.58.3.3

27. Avanzato D, Genova T, Fiorio Pla A, Bernardini M, Bianco S, Bussolati B, et al. Activation of $\mathrm{P} 2 \mathrm{X} 7$ and $\mathrm{P} 2 \mathrm{Y} 11$ purinergic receptors inhibits migration and normalizes tumor-derived endothelial cells via cAMP signaling. Sci Rep (2016) 6:32602. doi:10.1038/srep32602

28. Burnstock G, Di VF. Purinergic signalling and cancer. Purinergic Signal (2013) 9:491-540. doi:10.1007/s11302-013-9381-4

29. Burnstock G, Knight GE. Cellular distribution and functions of P2 receptor subtypes in different systems. Int Rev Cytol (2004) 240:31-304. doi:10.1016/ S0074-7696(04)40002-3

30. Bours MJ, Swennen EL, Di VF, Cronstein BN, Dagnelie PC. Adenosine 5 'triphosphate and adenosine as endogenous signaling molecules in immunity and inflammation. Pharmacol Ther (2006) 112:358-404. doi:10.1016/j. pharmthera.2005.04.013

31. Morandini AC, Savio LE, Coutinho-Silva R. The role of P2X7 receptor in infectious inflammatory diseases and the influence of ectonucleotidases. Biomed J (2014) 37:169-77. doi:10.4103/2319-4170.127803

32. Fredholm BB, IJzerman AP, Jacobson KA, Linden J, Muller CE. International union of basic and clinical pharmacology. LXXXI. Nomenclature and classification of adenosine receptors - an update. Pharmacol Rev (2011) 63:1-34. doi:10.1124/pr.110.003285

33. Volonte C, Amadio S, D’Ambrosi N, Colpi M, Burnstock G. P2 receptor web: complexity and fine-tuning. Pharmacol Ther (2006) 112:264-80. doi:10.1016/j.pharmthera.2005.04.012

34. Khakh BS, North RA. P2X receptors as cell-surface ATP sensors in health and disease. Nature (2006) 442:527-32. doi:10.1038/nature04886

35. Vaughn BP, Robson SC, Burnstock G. Pathological roles of purinergic signaling in the liver. J Hepatol (2012) 57:916-20. doi:10.1016/j.jhep.2012.06.008

36. Allard B, Longhi MS, Robson SC, Stagg J. The ectonucleotidases CD39 and CD73: novel checkpoint inhibitor targets. Immunol Rev (2017) 276:121-44. doi:10.1111/imr.12528

37. Robson SC, Sevigny J, Zimmermann H. The E-NTPDase family of ectonucleotidases: structure function relationships and pathophysiological significance. Purinergic Signal (2006) 2:409-30. doi:10.1007/s11302-0069003-5

38. Chen Y, Corriden R, Inoue Y, Yip L, Hashiguchi N, Zinkernagel A, et al. ATP release guides neutrophil chemotaxis via $\mathrm{P} 2 \mathrm{Y} 2$ and $\mathrm{A} 3$ receptors. Science (2006) 314:1792-5. doi:10.1126/science.1132559

39. Woehrle T, Yip L, Elkhal A, Sumi Y, Chen Y, Yao Y, et al. Pannexin-1 hemichannel-mediated ATP release together with $\mathrm{P} 2 \mathrm{X} 1$ and $\mathrm{P} 2 \mathrm{X} 4$ receptors regulate T-cell activation at the immune synapse. Blood (2010) 116:3475-84. doi:10.1182/blood-2010-04-277707

40. Yip L, Woehrle T, Corriden R, Hirsh M, Chen Y, Inoue Y, et al. Autocrine regulation of T-cell activation by ATP release and $\mathrm{P} 2 \mathrm{X} 7$ receptors. FASEB $J$ (2009) 23:1685-93. doi:10.1096/fj.08-126458

41. Aswad F, Kawamura H, Dennert G. High sensitivity of CD4+CD25+ regulatory $\mathrm{T}$ cells to extracellular metabolites nicotinamide adenine dinucleotide and ATP: a role for P2X7 receptors. J Immunol (2005) 175:3075-83. doi:10.4049/jimmunol.175.5.3075

42. Aymeric L, Apetoh L, Ghiringhelli F, Tesniere A, Martins I, Kroemer G, et al. Tumor cell death and ATP release prime dendritic cells and efficient anticancer immunity. Cancer Res (2010) 70:855-8. doi:10.1158/0008-5472. CAN-09-3566

43. Hausler SF, Montalban del Barrio I, Strohschein J, Chandran PA, Engel JB, Hönig A, et al. Ectonucleotidases CD39 and CD73 on OvCA cells are potent adenosine-generating enzymes responsible for adenosine receptor 2A-dependent suppression of T cell function and NK cell cytotoxicity. Cancer Immunol Immunother (2011) 60:1405-18. doi:10.1007/s00262-011-1040-4

44. Ryzhov S, Novitskiy SV, Goldstein AE, Biktasova A, Blackburn MR, Biaggioni I, et al. Adenosinergic regulation of the expansion and immunosuppressive activity of CD11b+Gr1+ cells. J Immunol (2011) 187:6120-9. doi:10.4049/jimmunol.1101225

45. Kerkelä E, Laitinen A, Räbinä J, Valkonen S, Takatalo M, Larjo A, et al. Adenosinergic immunosuppression by human mesenchymal stromal cells requires co-operation with T cells. Stem Cells (2016) 34:781-90. doi:10.1002/ stem. 2280

46. Adinolfi E, Capece M, Amoroso F, De ME, Franceschini A. Emerging roles of P2X receptors in cancer. Curr Med Chem (2015) 22:878-90. doi:10.2174/0 929867321666141012172913

47. Adinolfi E, Capece M, Franceschini A, Falzoni S, Giuliani AL, Rotondo A, et al. Accelerated tumor progression in mice lacking the ATP receptor P2X7. Cancer Res (2015) 75:635-44. doi:10.1158/0008-5472.CAN-14-1259

48. Bian S, Sun X, Bai A, Zhang C, Li L, Enjyoji K, et al. P2X7 integrates PI3K/ AKT and AMPK-PRAS40-mTOR signaling pathways to mediate tumor cell death. PLoS One (2013) 8:e60184. doi:10.1371/journal.pone.0060184

49. Xie R, Xu J, Wen G, Jin H, Liu X, Yang Y, et al. The P2Y2 nucleotide receptor mediates the proliferation and migration of human hepatocellular carcinoma cells induced by ATP. J Biol Chem (2014) 289:19137-49. doi:10.1074/jbc. M113.540047

50. Yang G, Zhang S, Zhang Y, Zhou Q, Peng S, Zhang T, et al. The inhibitory effects of extracellular ATP on the growth of nasopharyngeal carcinoma cells via P2Y2 receptor and osteopontin. J Exp Clin Cancer Res (2014) 33:53. doi:10.1186/1756-9966-33-53

51. Hatfield SM, Kjaergaard J, Lukashev D, Belikoff B, Schreiber TH, Sethumadhavan S, et al. Systemic oxygenation weakens the hypoxia and hypoxia inducible factor 1alpha-dependent and extracellular adenosinemediated tumor protection. J Mol Med (Berl) (2014) 92:1283-92. doi:10.1007/ s00109-014-1189-3

52. Mello Pde A, Filippi-Chiela EC, Nascimento J, Beckenkamp A, Santana DB, Kipper F, et al. Adenosine uptake is the major effector of extracellular ATP toxicity in human cervical cancer cells. Mol Biol Cell (2014) 25:2905-18. doi:10.1091/mbc.E14-01-0042

53. Di VF. P2RX7: a receptor with a split personality in inflammation and cancer. Mol Cell Oncol (2016) 3:e1010937. doi:10.1080/23723556.2015.1010937

54. Pellegatti P, Raffaghello L, Bianchi G, Piccardi F, Pistoia V, Di VF. Increased level of extracellular ATP at tumor sites: in vivo imaging with plasma membrane luciferase. PLoS One (2008) 3:e2599. doi:10.1371/journal. pone. 0002599

55. Falzoni S, Donvito G, Di VF. Detecting adenosine triphosphate in the pericellular space. Interface Focus (2013) 3:20120101. doi:10.1098/rsfs.2012.0101

56. Yegutkin GG. Enzymes involved in metabolism of extracellular nucleotides and nucleosides: functional implications and measurement of activities. Crit Rev Biochem Mol Biol (2014) 49:473-97. doi:10.3109/10409238.2014. 953627

57. Eltzschig HK, Sitkovsky MV, Robson SC. Purinergic signaling during inflammation. N Engl J Med (2012) 367:2322-33. doi:10.1056/NEJMra1205750

58. Kroemer G, Galluzzi L, Kepp O, Zitvogel L. Immunogenic cell death in cancer therapy. Annu Rev Immunol (2013) 31:51-72. doi:10.1146/ annurev-immunol-032712-100008 
59. Trautmann A. Extracellular ATP in the immune system: more than just a "danger signal". Sci Signal (2009) 2:e6. doi:10.1126/scisignal.256pe6

60. Ghiringhelli F, Apetoh L, Tesniere A, Aymeric L, Ma Y, Ortiz C, et al. Activation of the NLRP3 inflammasome in dendritic cells induces IL-1betadependent adaptive immunity against tumors. Nat Med (2009) 15:1170-8. doi:10.1038/nm.2028

61. Elliott MR, Chekeni FB, Trampont PC, Lazarowski ER, Kadl A, Walk SF, et al. Nucleotides released by apoptotic cells act as a find-me signal to promote phagocytic clearance. Nature (2009) 461:282-6. doi:10.1038/nature08296

62. Jacob F, Perez NC, Bachert C, Van CK. Purinergic signaling in inflammatory cells: P2 receptor expression, functional effects, and modulation of inflammatory responses. Purinergic Signal (2013) 9:285-306. doi:10.1007/ s11302-013-9357-4

63. Pelegrin P, Barroso-Gutierrez C, Surprenant A. P2X7 receptor differentially couples to distinct release pathways for IL-1beta in mouse macrophage. J Immunol (2008) 180:7147-57. doi:10.4049/jimmunol.180.11.7147

64. Garcia RA, Yan M, Search D, Zhang R, Carson NL, Ryan CS, et al. P2Y6 receptor potentiates pro-inflammatory responses in macrophages and exhibits differential roles in atherosclerotic lesion development. PLoS One (2014) 9:e111385. doi:10.1371/journal.pone.0111385

65. Savio LEB, de Andrade MP, Figliuolo VR, de Avelar Almeida TF, Santana PT, Oliveira SDS, et al. CD39 limits P2X7 receptor inflammatory signaling and attenuates sepsis-induced liver injury. J Hepatol (2017) 67:716-26. doi:10.1016/j.jhep.2017.05.021

66. Idzko M, Dichmann S, Ferrari D, Di Virgilio F, la Sala A, Girolomoni G, et al. Nucleotides induce chemotaxis and actin polymerization in immature but not mature human dendritic cells via activation of pertussis toxin-sensitive P2Y receptors. Blood (2002) 100:925-32. doi:10.1182/blood.V100.3.925

67. Marteau F, Communi D, Boeynaems JM, Suarez GN. Involvement of multiple $\mathrm{P} 2 \mathrm{Y}$ receptors and signaling pathways in the action of adenine nucleotides diphosphates on human monocyte-derived dendritic cells. JLeukoc Biol (2004) 76:796-803. doi:10.1189/jlb.0104032

68. Moreschi I, Bruzzone S, Bodrato N, Usai C, Guida L, Nicholas RA, et al. $\mathrm{NAADP}+$ is an agonist of the human P2Y11 purinergic receptor. Cell Calcium (2008) 43:344-55. doi:10.1016/j.ceca.2007.06.006

69. Wang L, Jacobsen SE, Bengtsson A, Erlinge D. P2 receptor mRNA expression profiles in human lymphocytes, monocytes and $\mathrm{CD} 34+$ stem and progenitor cells. BMC Immunol (2004) 5:16. doi:10.1186/1471-2172-5-16

70. Overes IM, de Rijke B, van Horssen-Zoetbrood A, Fredrix H, de Graaf AO, Jansen JH, et al. Expression of P2X5 in lymphoid malignancies results in LRH-1-specific cytotoxic T-cell-mediated lysis. Br J Haematol (2008) 141:799-807. doi:10.1111/j.1365-2141.2008.07125.x

71. Tsukimoto M, Tokunaga A, Harada H, Kojima S. Blockade of murine T cell activation by antagonists of P2Y6 and P2X7 receptors. Biochem Biophys Res Commun (2009) 384:512-8. doi:10.1016/j.bbrc.2009.05.011

72. Schenk U, Westendorf AM, Radaelli E, Casati A, Ferro M, Fumagalli M, et al. Purinergic control of T cell activation by ATP released through pannexin-1 hemichannels. Sci Signal (2008) 1:ra6. doi:10.1126/scisignal.1160583

73. Beldi G, Wu Y, Banz Y, Nowak M, Miller L, Enjyoji K, et al. Natural killer T cell dysfunction in CD39-null mice protects against concanavalin A-induced hepatitis. Hepatology (2008) 48:841-52. doi:10.1002/hep.22401

74. Figliuolo VR, Savio LEB, Safya H, Nanini H, Bernardazzi C, Abalo A, et al. P2X7 receptor promotes intestinal inflammation in chemically induced colitis and triggers death of mucosal regulatory T cells. Biochim Biophys Acta (2017) 1863:1183-94. doi:10.1016/j.bbadis.2017.03.004

75. Schenk U, Frascoli M, Proietti M, Geffers R, Traggiai E, Buer J, et al. ATP inhibits the generation and function of regulatory $\mathrm{T}$ cells through the activation of purinergic P2X receptors. Sci Signal (2011) 4:ra12. doi:10.1126/ scisignal.2001270

76. Mascanfroni ID, Takenaka MC, Yeste A, Patel B, Wu Y, Kenison JE, et al. Metabolic control of type 1 regulatory T cell differentiation by AHR and HIF1-alpha. Nat Med (2015) 21:638-46. doi:10.1038/nm.3868

77. Pandolfi JB, Ferraro AA, Sananez I, Gancedo MC, Baz P, Billordo LA, et al. ATP-induced inflammation drives tissue-resident Th17 cells in metabolically unhealthy obesity. J Immunol (2016) 196:3287-96. doi:10.4049/ jimmunol.1502506

78. Atarashi K, Nishimura J, Shima T, Umesaki Y, Yamamoto M, Onoue M, et al. ATP drives lamina propria T(H)17 cell differentiation. Nature (2008) 455:808-12. doi:10.1038/nature07240
79. Hofman P, Cherfils-Vicini J, Bazin M, Ilie M, Juhel T, Hébuterne X, et al. Genetic and pharmacological inactivation of the purinergic P2RX7 receptor dampens inflammation but increases tumor incidence in a mouse model of colitis-associated cancer. Cancer Res (2015) 75:835-45. doi:10.1158/00085472.CAN-14-1778

80. Khalid M, Brisson L, Tariq M, Hao Y, Guibon R, Fromont G, et al. Carcinoma-specific expression of P2Y11 receptor and its contribution in ATP-induced purinergic signalling and cell migration in human hepatocellular carcinoma cells. Oncotarget (2017) 8:37278-90. doi:10.18632/ oncotarget.16191

81. Li WH, Qiu Y, Zhang HQ, Liu Y, You JF, Tian XX, et al. P2Y2 receptor promotes cell invasion and metastasis in prostate cancer cells. Br J Cancer (2013) 109:1666-75. doi:10.1038/bjc.2013.484

82. Li WH, Qiu Y, Zhang HQ, Tian XX, Fang WG. P2Y2 receptor and EGFR cooperate to promote prostate cancer cell invasion via ERK1/2 pathway. PLoS One (2015) 10:e0133165. doi:10.1371/journal.pone.0133165

83. Joo YN, Jin H, Eun SY, Park SW, Chang KC, Kim HJ. P2Y2R activation by nucleotides released from the highly metastatic breast cancer cell MDA-MB-231 contributes to pre-metastatic niche formation by mediating lysyl oxidase secretion, collagen crosslinking, and monocyte recruitment. Oncotarget (2014) 5:9322-34. doi:10.18632/oncotarget.2427

84. Zhang JL, Liu Y, Yang H, Zhang HQ, Tian XX, Fang WG. ATP-P2Y2-betacatenin axis promotes cell invasion in breast cancer cells. Cancer Sci (2017) 108:1318-27. doi:10.1111/cas.13273

85. Chadet S, Jelassi B, Wannous R, Angoulvant D, Chevalier S, Besson P, et al. The activation of $\mathrm{P} 2 \mathrm{Y} 2$ receptors increases MCF-7 breast cancer cells migration through the MEK-ERK1/2 signalling pathway. Carcinogenesis (2014) 35:1238-47. doi:10.1093/carcin/bgt493

86. Jin H, Eun SY, Lee JS, Park SW, Lee JH, Chang KC, et al. P2Y2 receptor activation by nucleotides released from highly metastatic breast cancer cells increases tumor growth and invasion via crosstalk with endothelial cells. Breast Cancer Res (2014) 16:R77. doi:10.1186/bcr3694

87. Eun SY, Ko YS, Park SW, Chang KC, Kim HJ. P2Y2 nucleotide receptormediated extracellular signal-regulated kinases and protein kinase $C$ activation induces the invasion of highly metastatic breast cancer cells. Oncol Rep (2015) 34:195-202. doi:10.3892/or.2015.3972

88. Höpfner M, Maaser K, Barthel B, von Lampe B, Hanski C, Riecken EO, et al. Growth inhibition and apoptosis induced by $\mathrm{P} 2 \mathrm{Y} 2$ receptors in human colorectal carcinoma cells: involvement of intracellular calcium and cyclic adenosine monophosphate. Int J Colorectal Dis (2001) 16:154-66. doi:10.1007/ s003840100302

89. Coutinho-Silva R, Stahl L, Cheung KK, de Campos NE, de Oliveira Souza C, Ojcius DM, et al. P2X and P2Y purinergic receptors on human intestinal epithelial carcinoma cells: effects of extracellular nucleotides on apoptosis and cell proliferation. Am J Physiol Gastrointest Liver Physiol (2005) 288:G1024-35. doi:10.1152/ajpgi.00211.2004

90. White N, Ryten M, Clayton E, Butler P, Burnstock G. P2Y purinergic receptors regulate the growth of human melanomas. Cancer Lett (2005) 224:81-91. doi:10.1016/j.canlet.2004.11.027

91. Wei Q, Costanzi S, Liu QZ, Gao ZG, Jacobson KA. Activation of the P2Y1 receptor induces apoptosis and inhibits proliferation of prostate cancer cells. Biochem Pharmacol (2011) 82:418-25. doi:10.1016/j.bcp.2011.05.013

92. Maynard JP, Lee JS, Sohn BH, Yu X, Lopez-Terrada D, Finegold MJ, et al. P2X3 purinergic receptor overexpression is associated with poor recurrence-free survival in hepatocellular carcinoma patients. Oncotarget (2015) 6:41162-79. doi:10.18632/oncotarget.6240

93. Greig AV, Linge C, Healy V, Lim P, Clayton E, Rustin MH, et al. Expression of purinergic receptors in non-melanoma skin cancers and their functional roles in A431 cells. J Invest Dermatol (2003) 121:315-27. doi:10.1046/j.1523-1747.2003.12379.x

94. Surprenant A, Rassendren F, Kawashima E, North RA, Buell G. The cytolytic P2Z receptor for extracellular ATP identified as a P2X receptor (P2X7). Science (1996) 272:735-8. doi:10.1126/science.272.5262.735

95. Rassendren F, Buell GN, Virginio C, Collo G, North RA, Surprenant A. The permeabilizing ATP receptor, P2X7. Cloning and expression of a human cDNA. J Biol Chem (1997) 272:5482-6. doi:10.1074/jbc.272.9.5482

96. Di Virgilio F, Chiozzi P, Falzoni S, Ferrari D, Sanz JM, Venketaraman V, et al. Cytolytic P2X purinoceptors. Cell Death Differ (1998) 5:191-9. doi:10.1038/ sj.cdd. 4400341 
97. Baricordi OR, Ferrari D, Melchiorri L, Chiozzi P, Hanau S, Chiari E, et al. An ATP-activated channel is involved in mitogenic stimulation of human T lymphocytes. Blood (1996) 87:682-90.

98. Adinolfi E, Melchiorri L, Falzoni S, Chiozzi P, Morelli A, Tieghi A, et al. P2X7 receptor expression in evolutive and indolent forms of chronic B lymphocytic leukemia. Blood (2002) 99:706-8. doi:10.1182/blood.V99.2.706

99. Adinolfi E, Callegari MG, Ferrari D, Bolognesi C, Minelli M, Wieckowski MR, et al. Basal activation of the P2X7 ATP receptor elevates mitochondrial calcium and potential, increases cellular ATP levels, and promotes serum-independent growth. Mol Biol Cell (2005) 16:3260-72. doi:10.1091/ mbc.E04-11-1025

100. Adinolfi E, Raffaghello L, Giuliani AL, Cavazzini L, Capece M, Chiozzi P, et al. Expression of P2X7 receptor increases in vivo tumor growth. Cancer Res (2012) 72:2957-69. doi:10.1158/0008-5472.CAN-11-1947

101. Amoroso F, Capece M, Rotondo A, Cangelosi D, Ferracin M, Franceschini A, et al. The P2X7 receptor is a key modulator of the PI3K/GSK3beta/VEGF signaling network: evidence in experimental neuroblastoma. Oncogene (2015) 34:5240-51. doi:10.1038/onc.2014.444

102. Adinolfi E, Callegari MG, Cirillo M, Pinton P, Giorgi C, Cavagna D, et al. Expression of the $\mathrm{P} 2 \mathrm{X} 7$ receptor increases the $\mathrm{Ca} 2+$ content of the endoplasmic reticulum, activates NFATc1, and protects from apoptosis. J Biol Chem (2009) 284:10120-8. doi:10.1074/jbc.M805805200

103. Tafani M, Schito L, Pellegrini L, Villanova L, Marfe G, Anwar T, et al. Hypoxia-increased RAGE and P2X7R expression regulates tumor cell invasion through phosphorylation of Erk1/2 and Akt and nuclear translocation of NF-\{kappa\}B. Carcinogenesis (2011) 32:1167-75. doi:10.1093/ carcin/bgr101

104. Qiu Y, Li WH, Zhang HQ, Liu Y, Tian XX, Fang WG. P2X7 mediates ATPdriven invasiveness in prostate cancer cells. PLoS One (2014) 9:e114371. doi:10.1371/journal.pone.0114371

105. Zhang XJ, Zheng GG, Ma XT, Yang YH, Li G, Rao Q, et al. Expression of P2X7 in human hematopoietic cell lines and leukemia patients. Leuk Res (2004) 28:1313-22. doi:10.1016/j.leukres.2004.04.001

106. Chong JH, Zheng GG, Zhu XF, Guo Y, Wang L, Ma CH, et al. Abnormal expression of P2X family receptors in Chinese pediatric acute leukemias. Biochem Biophys Res Commun (2010) 391:498-504. doi:10.1016/j. bbrc.2009.11.087

107. Deli T, Varga N, Adám A, Kenessey I, Rásó E, Puskás LG, et al. Functional genomics of calcium channels in human melanoma cells. Int J Cancer (2007) 121:55-65. doi:10.1002/ijc.22621

108. Raffaghello L, Chiozzi P, Falzoni S, Di VF, Pistoia V. The P2X7 receptor sustains the growth of human neuroblastoma cells through a substance P-dependent mechanism. Cancer Res (2006) 66:907-14. doi:10.1158/00085472.CAN-05-3185

109. Giannuzzo A, Pedersen SF, Novak I. The P2X7 receptor regulates cell survival, migration and invasion of pancreatic ductal adenocarcinoma cells. Mol Cancer (2015) 14:203. doi:10.1186/s12943-015-0472-4

110. Santos AA Jr, Cappellari AR, de Marchi FO, Gehring MP, Zaparte A, Brandão CA, et al. Potential role of P2X7R in esophageal squamous cell carcinoma proliferation. Purinergic Signal (2017) 13:279-92. doi:10.1007/ s11302-017-9559-2

111. Tan C, Han LI, Zou L, Luo C, Liu A, Sheng X, et al. Expression of P2X7R in breast cancer tissue and the induction of apoptosis by the gene-specific shRNA in MCF-7 cells. Exp Ther Med (2015) 10:1472-8. doi:10.3892/ etm.2015.2705

112. Ghalali A, Wiklund F, Zheng H, Stenius U, Hogberg J. Atorvastatin prevents ATP-driven invasiveness via P2X7 and EHBP1 signaling in PTEN-expressing prostate cancer cells. Carcinogenesis (2014) 35:1547-55. doi:10.1093/carcin/ bgu019

113. Kwon JH, Nam ES, Shin HS, Cho SJ, Park HR, Kwon MJ. P2X7 receptor expression in coexistence of papillary thyroid carcinoma with Hashimoto's thyroiditis. Korean J Pathol (2014) 48:30-5. doi:10.4132/KoreanJPathol.2014.48.1.30

114. Bae JY, Lee SW, Shin YH, Lee JH, Jahng JW, Park K. P2X7 receptor and NLRP3 inflammasome activation in head and neck cancer. Oncotarget (2017) 8:48972-82. doi:10.18632/oncotarget.16903

115. Jelassi B, Chantôme A, Alcaraz-Pérez F, Baroja-Mazo A, Cayuela ML, Pelegrin P, et al. P2X(7) receptor activation enhances SK3 channels- and cystein cathepsin-dependent cancer cells invasiveness. Oncogene (2011) 30:2108-22. doi:10.1038/onc.2010.593
116. Ohta A, Gorelik E, Prasad SJ, Ronchese F, Lukashev D, Wong MK, et al. A2A adenosine receptor protects tumors from antitumor T cells. Proc Natl Acad Sci U S A (2006) 103:13132-7. doi:10.1073/pnas.0605251103

117. Blay J, White TD, Hoskin DW. The extracellular fluid of solid carcinomas contains immunosuppressive concentrations of adenosine. Cancer Res (1997) 57:2602-5.

118. Sitkovsky MV, Hatfield S, Abbott R, Belikoff B, Lukashev D, Ohta A. Hostile, hypoxia-A2-adenosinergic tumor biology as the next barrier to overcome for tumor immunologists. Cancer Immunol Res (2014) 2:598-605. doi:10.1158/2326-6066.CIR-14-0075

119. Antonioli L, Pacher P, Vizi ES, Hasko G. CD39 and CD73 in immunity and inflammation. Trends Mol Med (2013) 19:355-67. doi:10.1016/j. molmed.2013.03.005

120. Stagg J, Smyth MJ. Extracellular adenosine triphosphate and adenosine in cancer. Oncogene (2010) 29:5346-58. doi:10.1038/onc.2010.292

121. BastidJ,Cottalorda-RegairazA,AlbericiG,BonnefoyN,EliaouJF,Bensussan A. ENTPD1/CD39 is a promising therapeutic target in oncology. Oncogene (2013) 32:1743-51. doi:10.1038/onc.2012.269

122. Allard D, Allard B, Gaudreau PO, Chrobak P, Stagg J. CD73-adenosine: a next-generation target in immuno-oncology. Immunotherapy (2016) 8:145-63. doi:10.2217/imt.15.106

123. Jin D, Fan J, Wang L, Thompson LF, Liu A, Daniel BJ, et al. CD73 on tumor cells impairs antitumor T-cell responses: a novel mechanism of tumor-induced immune suppression. Cancer Res (2010) 70:2245-55. doi:10.1158/00085472.CAN-09-3109

124. Häusler SF, Del Barrio IM, Diessner J, Stein RG, Strohschein J, Hönig A, et al. Anti-CD39 and anti-CD73 antibodies A1 and 7G2 improve targeted therapy in ovarian cancer by blocking adenosine-dependent immune evasion. Am J Transl Res (2014) 6:129-39.

125. Beavis PA, Divisekera U, Paget C, Chow MT, John LB, Devaud C, et al. Blockade of A2A receptors potently suppresses the metastasis of CD73+ tumors. Proc Natl Acad Sci U S A (2013) 110:14711-6. doi:10.1073/pnas.1308209110

126. Serra S, Horenstein AL, Vaisitti T, Brusa D, Rossi D, Laurenti L, et al. CD73-generated extracellular adenosine in chronic lymphocytic leukemia creates local conditions counteracting drug-induced cell death. Blood (2011) 118:6141-52. doi:10.1182/blood-2011-08-374728

127. Wang L, Fan J, Thompson LF, Zhang Y, Shin T, Curiel TJ, et al. CD73 has distinct roles in nonhematopoietic and hematopoietic cells to promote tumor growth in mice. J Clin Invest (2011) 121:2371-82. doi:10.1172/JCI45559

128. Mandapathil M, Szczepanski MJ, Szajnik M, Ren J, Lenzner DE, Jackson EK, et al. Increased ectonucleotidase expression and activity in regulatory $\mathrm{T}$ cells of patients with head and neck cancer. Clin Cancer Res (2009) 15:6348-57. doi:10.1158/1078-0432.CCR-09-1143

129. Chalmin F, Mignot G, Bruchard M, Chevriaux A, Végran F, Hichami A, et al. Stat 3 and Gfi-1 transcription factors control Th17 cell immunosuppressive activity via the regulation of ectonucleotidase expression. Immunity (2012) 36:362-73. doi:10.1016/j.immuni.2011.12.019

130. Thibaudin $M$, Chaix $M$, Boidot $R$, Végran F, Derangère V, Limagne $E$, et al. Human ectonucleotidase-expressing CD25high Th17 cells accumulate in breast cancer tumors and exert immunosuppressive functions. Oncoimmunology (2016) 5:e1055444. doi:10.1080/2162402X.2015.1055444

131. Ryzhov S, Biktasova A, Goldstein AE, Zhang Q, Biaggioni I, Dikov MM, et al. Role of JunB in adenosine A2B receptor-mediated vascular endothelial growth factor production. Mol Pharmacol (2014) 85:62-73. doi:10.1124/ mol.113.088567

132. Shevchenko I, Bazhin AV, Umansky V. Comment on "Adenosinergic regulation of the expansion and immunosuppressive activity of CD11b(+) Gr1(+) cells". J Immunol (2012) 188:2929-30. doi:10.4049/jimmunol.1290007

133. Wang L, Tang S, Wang Y, Xu S, Yu J, Zhi X, et al. Ecto-5'-nucleotidase (CD73) promotes tumor angiogenesis. Clin Exp Metastasis (2013) 30:671-80. doi:10.1007/s10585-013-9571-z

134. Allard B, Turcotte M, Spring K, Pommey S, Royal I, Stagg J. Anti-CD73 therapy impairs tumor angiogenesis. Int J Cancer (2014) 134:1466-73. doi:10.1002/ijc.28456

135. Turcotte M, Spring K, Pommey S, Chouinard G, Cousineau I, George J, et al. CD73 is associated with poor prognosis in high-grade serous ovarian cancer. Cancer Res (2015) 75:4494-503. doi:10.1158/0008-5472.CAN-14-3569

136. Mediavilla-Varela M, Luddy K, Noyes D, Khalil FK, Neuger AM, Soliman H, et al. Antagonism of adenosine A2A receptor expressed by lung 
adenocarcinoma tumor cells and cancer associated fibroblasts inhibits their growth. Cancer Biol Ther (2013) 14:860-8. doi:10.4161/cbt.25643

137. Sattler C, Steinsdoerfer M, Offers M, Fischer E, Schierl R, Heseler K, et al. Inhibition of T-cell proliferation by murine multipotent mesenchymal stromal cells is mediated by CD39 expression and adenosine generation. Cell Transplant (2011) 20:1221-30. doi:10.3727/096368910X546553

138. Clayton A, Al-Taei S, Webber J, Mason MD, Tabi Z. Cancer exosomes express $\mathrm{CD} 39$ and $\mathrm{CD} 73$, which suppress $\mathrm{T}$ cells through adenosine production. J Immunol (2011) 187:676-83. doi:10.4049/jimmunol.1003884

139. Smyth LA, Ratnasothy K, Tsang JY, Boardman D, Warley A, Lechler R, et al. CD73 expression on extracellular vesicles derived from CD4+ CD25+ Foxp3+ T cells contributes to their regulatory function. Eur J Immunol (2013) 43:2430-40. doi:10.1002/eji.201242909

140. Yegutkin GG. Nucleotide- and nucleoside-converting ectoenzymes: important modulators of purinergic signalling cascade. Biochim Biophys Acta (2008) 1783:673-94. doi:10.1016/j.bbamcr.2008.01.024

141. Schulte G, Fredholm BB. Signalling from adenosine receptors to mitogenactivated protein kinases. Cell Signal (2003) 15:813-27. doi:10.1016/S08986568(03)00058-5

142. Yang D, Zhang Y, Nguyen HG, Koupenova M, Chauhan AK, Makitalo M, et al. The A2B adenosine receptor protects against inflammation and excessive vascular adhesion. J Clin Invest (2006) 116:1913-23. doi:10.1172/ JCI27933

143. Hasko G, Csoka B, Nemeth ZH, Vizi ES, Pacher P. A(2B) adenosine receptors in immunity and inflammation. Trends Immunol (2009) 30:263-70. doi:10.1016/j.it.2009.04.001

144. Ohta A, Sitkovsky M. Role of G-protein-coupled adenosine receptors in downregulation of inflammation and protection from tissue damage. Nature (2001) 414:916-20. doi:10.1038/414916a

145. Choukèr A, Thiel M, Lukashev D, Ward JM, Kaufmann I, Apasov S, et al. Critical role of hypoxia and A2A adenosine receptors in liver tissueprotecting physiological anti-inflammatory pathway. Mol Med (2008) 14:116-23. doi:10.2119/2007-00075.Chouker

146. Ohta A, Ohta A, Madasu M, Kini R, Subramanian M, Goel N, et al. A2A adenosine receptor may allow expansion of $\mathrm{T}$ cells lacking effector functions in extracellular adenosine-rich microenvironments. J Immunol (2009) 183:5487-93. doi:10.4049/jimmunol.0901247

147. Novitskiy SV, Ryzhov S, Zaynagetdinov R, Goldstein AE, Huang Y, Tikhomirov OY, et al. Adenosine receptors in regulation of dendritic cell differentiation and function. Blood (2008) 112:1822-31. doi:10.1182/ blood-2008-02-136325

148. Zarek PE, Huang CT, Lutz ER, Kowalski J, Horton MR, Linden J, et al. A2A receptor signaling promotes peripheral tolerance by inducing T-cell anergy and the generation of adaptive regulatory T cells. Blood (2008) 111:251-9. doi:10.1182/blood-2007-03-081646

149. Romio M, Reinbeck B, Bongardt S, Huls S, BurghoffS, Schrader J. Extracellular purine metabolism and signaling of CD73-derived adenosine in murine Treg and Teff cells. Am J Physiol Cell Physiol (2011) 301:C530-9. doi:10.1152/ ajpcell.00385.2010

150. Hatfield SM, Kjaergaard J, Lukashev D, Schreiber TH, Belikoff B, Abbott R, et al. Immunological mechanisms of the antitumor effects of supplemental oxygenation. Sci Transl Med (2015) 7:277ra30. doi:10.1126/scitranslmed. aaa 1260

151. Ohta A, Kini R, Ohta A, Subramanian M, Madasu M, Sitkovsky M. The development and immunosuppressive functions of CD4(+) CD25(+) FoxP3(+) regulatory $\mathrm{T}$ cells are under influence of the adenosine- $\mathrm{A} 2 \mathrm{~A}$ adenosine receptor pathway. Front Immunol (2012) 3:190. doi:10.3389/ fimmu. 2012.00190

152. Kinsey GR, Huang L, Jaworska K, Khutsishvili K, Becker DA, Ye H, et al. Autocrine adenosine signaling promotes regulatory $\mathrm{T}$ cell-mediated renal protection. J Am Soc Nephrol (2012) 23:1528-37. doi:10.1681/ASN. 2012010070

153. Cekic C, Day YJ, Sag D, Linden J. Myeloid expression of adenosine A2A receptor suppresses $\mathrm{T}$ and $\mathrm{NK}$ cell responses in the solid tumor microenvironment. Cancer Res (2014) 74:7250-9. doi:10.1158/0008-5472.CAN-13-3583

154. Vuaden FC, Savio LE, Ramos DB, Casali EA, Bogo MR, Bonan CD. Endotoxin-induced effects on nucleotide catabolism in mouse kidney. Eur J Pharmacol (2012) 674:422-9. doi:10.1016/j.ejphar.2011.11.002
155. Vuaden FC, Savio LE, Bastos CM, Bogo MR, Bonan CD. Adenosine A(2A) receptor agonist (CGS-21680) prevents endotoxin-induced effects on nucleotidase activities in mouse lymphocytes. Eur J Pharmacol (2011) 651:212-7. doi:10.1016/j.ejphar.2010.11.003

156. Ehrentraut H, Westrich JA, Eltzschig HK, Clambey ET. Adora2b adenosine receptor engagement enhances regulatory $\mathrm{T}$ cell abundance during endotoxin-induced pulmonary inflammation. PLoS One (2012) 7:e32416. doi:10.1371/journal.pone.0032416

157. Ryzhov SV, Pickup MW, Chytil A, Gorska AE, Zhang Q, Owens P, et al. Role of TGF-beta signaling in generation of CD39+CD73+ myeloid cells in tumors. J Immunol (2014) 193:3155-64. doi:10.4049/jimmunol.1400578

158. Barletta KE, Ley K, Mehrad B. Regulation of neutrophil function by adenosine. Arterioscler Thromb Vasc Biol (2012) 32:856-64. doi:10.1161/ ATVBAHA.111.226845

159. Allard B, Turcotte M, Stagg J. CD73-generated adenosine: orchestrating the tumor-stroma interplay to promote cancer growth. J Biomed Biotechnol (2012) 2012:485156. doi:10.1155/2012/485156

160. Gessi S, Merighi S, Sacchetto V, Simioni C, Borea PA. Adenosine receptors and cancer. Biochim Biophys Acta (2011) 1808:1400-12. doi:10.1016/j. bbamem.2010.09.020

161. Mirza A, Basso A, Black S, Malkowski M, Kwee L, Pachter JA, et al. RNA interference targeting of $\mathrm{A} 1$ receptor-overexpressing breast carcinoma cells leads to diminished rates of cell proliferation and induction of apoptosis. Cancer Biol Ther (2005) 4:1355-60. doi:10.4161/cbt.4.12.2196

162. Woodhouse EC, Amanatullah DF, Schetz JA, Liotta LA, Stracke ML, Clair T. Adenosine receptor mediates motility in human melanoma cells. Biochem Biophys Res Commun (1998) 246:888-94. doi:10.1006/bbrc.1998.8714

163. D’Ancona S, Ragazzi E, Fassina G, Mazzo M, Gusella M, Berti T. Effect of dipyridamole, 5'-(N-ethyl)-carboxamidoadenosine and 1,3-dipropyl-8(2-amino-4-chlorophenyl)-xanthine on LOVO cell growth and morphology. Anticancer Res (1994) 14:93-7.

164. Shaban M, Smith RA, Stone TW. Purine suppression of proliferation of Sertoli-like TM4 cells in culture. Cell Prolif (1995) 28:673-82. doi:10.1111/ j.1365-2184.1995.tb00053.x

165. Bowser JL, Blackburn MR, Shipley GL, Molina JG, Dunner KJr, Broaddus RR. Loss of CD73-mediated actin polymerization promotes endometrial tumor progression. J Clin Invest (2016) 126:220-38. doi:10.1172/JCI79380

166. Etique N, Grillier-Vuissoz I, Lecomte J, Flament S. Crosstalk between adenosine receptor (A2A isoform) and ERalpha mediates ethanol action in MCF-7 breast cancer cells. Oncol Rep (2009) 21:977-81. doi:10.3892/or_00000311

167. Merighi S, Mirandola P, Milani D, Varani K, Gessi S, Klotz KN, et al. Adenosine receptors as mediators of both cell proliferation and cell death of cultured human melanoma cells. J Invest Dermatol (2002) 119:923-33. doi:10.1046/j.1523-1747.2002.00111.x

168. Kasama H, Sakamoto Y, Kasamatsu A, Okamoto A, Koyama T, Minakawa Y, et al. Adenosine A2b receptor promotes progression of human oral cancer. BMC Cancer (2015) 15:563. doi:10.1186/s12885-015-1577-2

169. Fishman P, Bar-Yehuda S, Synowitz M, Powell JD, Klotz KN, Gessi S, et al. Adenosine receptors and cancer. Handb Exp Pharmacol (2009) 193:399-441. doi:10.1007/978-3-540-89615-9_14

170. Ntantie E, Gonyo P, Lorimer EL, Hauser AD, Schuld N, McAllister D, et al. An adenosine-mediated signaling pathway suppresses prenylation of the GTPase Rap1B and promotes cell scattering. Sci Signal (2013) 6:ra39. doi:10.1126/ scisignal.2003374

171. Kohno Y, Sei Y, Koshiba M, Kim HO, Jacobson KA. Induction of apoptosis in HL-60 human promyelocytic leukemia cells by adenosine A(3) receptor agonists. Biochem Biophys Res Commun (1996) 219:904-10. doi:10.1006/ bbrc.1996.0331

172. Gessi S, Varani K, Merighi S, Cattabriga E, Iannotta V, Leung E, et al. A(3) adenosine receptors in human neutrophils and promyelocytic HL60 cells: a pharmacological and biochemical study. Mol Pharmacol (2002) 61:415-24. doi:10.1124/mol.61.2.415

173. Gessi S, Varani K, Merighi S, Morelli A, Ferrari D, Leung E, et al. Pharmacological and biochemical characterization of A3 adenosine receptors in Jurkat T cells. Br J Pharmacol (2001) 134:116-26. doi:10.1038/ sj.bjp. 0704254

174. Yao Y, Sei Y, Abbracchio MP, Jiang JL, Kim YC, Jacobson KA. Adenosine A3 receptor agonists protect HL-60 and U-937 cells from apoptosis induced 
by A3 antagonists. Biochem Biophys Res Commun (1997) 232:317-22. doi:10.1006/bbrc. 1997.6290

175. Gessi S, Fogli E, Sacchetto V, Merighi S, Varani K, Preti D, et al. Adenosine modulates HIF-1 \{alpha\}, VEGF, IL-8, and foam cell formation in a human model of hypoxic foam cells. Arterioscler Thromb Vasc Biol (2010) 30:90-7. doi:10.1161/ATVBAHA.109.194902

176. Fishman P, Bar-Yehuda S, Ohana G, Pathak S, Wasserman L, Barer F, et al. Adenosine acts as an inhibitor of lymphoma cell growth: a major role for the A3 adenosine receptor. Eur J Cancer (2000) 36:1452-8. doi:10.1016/ S0959-8049(00)00130-1

177. Merighi S, Varani K, Gessi S, Cattabriga E, Iannotta V, Ulouglu C, et al. Pharmacological and biochemical characterization of adenosine receptors in the human malignant melanoma A375 cell line. Br J Pharmacol (2001) 134:1215-26. doi:10.1038/sj.bjp.0704352

178. Suh BC, Kim TD, Lee JU, Seong JK, Kim KT. Pharmacological characterization of adenosine receptors in PGT-beta mouse pineal gland tumour cells. Br J Pharmacol (2001) 134:132-42. doi:10.1038/sj.bjp.0704218

179. Gessi S, Sacchetto V, Fogli E, Merighi S, Varani K, Baraldi PG, et al. Modulation of metalloproteinase-9 in U87MG glioblastoma cells by A3 adenosine receptors. Biochem Pharmacol (2010) 79:1483-95. doi:10.1016/j. bcp.2010.01.009

180. Merighi S, Benini A, Mirandola P, Gessi S, Varani K, Leung E, et al. Adenosine modulates vascular endothelial growth factor expression via hypoxia-inducible factor-1 in human glioblastoma cells. Biochem Pharmacol (2006) 72:19-31. doi:10.1016/j.bcp.2006.03.020

181. Jajoo S, Mukherjea D, Watabe K, Ramkumar V. Adenosine A(3) receptor suppresses prostate cancer metastasis by inhibiting NADPH oxidase activity. Neoplasia (2009) 11:1132-45. doi:10.1593/neo.09744

182. Madi L, Ochaion A, Rath-Wolfson L, Bar-Yehuda S, Erlanger A, Ohana G, et al. The A3 adenosine receptor is highly expressed in tumor versus normal cells: potential target for tumor growth inhibition. Clin Cancer Res (2004) 10:4472-9. doi:10.1158/1078-0432.CCR-03-0651

183. Morello S, Petrella A, Festa M, Popolo A, Monaco M, Vuttariello E, et al. Cl-IB-MECA inhibits human thyroid cancer cell proliferation independently of A3 adenosine receptor activation. Cancer Biol Ther (2008) 7:278-84. doi:10.4161/cbt.7.2.5301

184. Bar-Yehuda S, Stemmer SM, Madi L, Castel D, Ochaion A, Cohen S, et al. The A3 adenosine receptor agonist CF102 induces apoptosis of hepatocellular carcinoma via de-regulation of the Wnt and NF-kappaB signal transduction pathways. Int J Oncol (2008) 33:287-95. doi:10.3892/ijo_00000008

185. Fishman P, Bar-Yehuda S, Barer F, Madi L, Multani AS, Pathak S. The A3 adenosine receptor as a new target for cancer therapy and chemoprotection. Exp Cell Res (2001) 269:230-6. doi:10.1006/excr.2001.5327

186. Fishman P, Madi L, Bar-Yehuda S, Barer F, Del VL, Khalili K. Evidence for involvement of Wnt signaling pathway in IB-MECA mediated suppression of melanoma cells. Oncogene (2002) 21:4060-4. doi:10.1038/sj.onc.1205531

187. Fishman P, Bar-Yehuda S, Madi L, Cohn I. A3 adenosine receptor as a target for cancer therapy. Anticancer Drugs (2002) 13:437-43. doi:10.1097/00001813-200206000-00001

188. Fishman P, Bar-Yehuda S, Ardon E, Rath-Wolfson L, Barrer F, Ochaion A, et al. Targeting the A3 adenosine receptor for cancer therapy: inhibition of prostate carcinoma cell growth by A3AR agonist. Anticancer Res (2003) 23:2077-83

189. Ohana G, Bar-Yehuda S, Arich A, Madi L, Dreznick Z, Rath-Wolfson L, et al. Inhibition of primary colon carcinoma growth and liver metastasis by the A3 adenosine receptor agonist CF101. Br J Cancer (2003) 89:1552-8. doi:10.1038/sj.bjc.6601315

190. Borea PA, Varani K, Vincenzi F, Baraldi PG, Tabrizi MA, Merighi S, et al. The A3 adenosine receptor: history and perspectives. Pharmacol Rev (2015) 67:74-102. doi:10.1124/pr.113.008540

191. Stemmer SM, Benjaminov O, Medalia G, Ciuraru NB, Silverman MH, Bar-Yehuda S, et al. CF102 for the treatment of hepatocellular carcinoma: a phase I/II, open-label, dose-escalation study. Oncologist (2013) 18:25-6. doi:10.1634/theoncologist.2012-0211

192. Saitoh M, Nagai K, Nakagawa K, Yamamura T, Yamamoto S, Nishizaki T. Adenosine induces apoptosis in the human gastric cancer cells via an intrinsic pathway relevant to activation of AMP-activated protein kinase. Biochem Pharmacol (2004) 67:2005-11. doi:10.1016/j.bcp.2004.01.020
193. Nogi Y, Kanno T, Nakano T, Fujita Y, Tabata C, Fukuoka K, et al. AMP converted from intracellularly transported adenosine upregulates p53 expression to induce malignant pleural mesothelioma cell apoptosis. Cell Physiol Biochem (2012) 30:61-74. doi:10.1159/000339048

194. Schrier SM, van Tilburg EW, van der Meulen H, IJzerman AP, Mulder GJ, Nagelkerke JF. Extracellular adenosine-induced apoptosis in mouse neuroblastoma cells: studies on involvement of adenosine receptors and adenosine uptake. Biochem Pharmacol (2001) 61:417-25. doi:10.1016/ S0006-2952(00)00573-6

195. Sai K, Yang D, Yamamoto H, Fujikawa H, Yamamoto S, Nagata T, et al. A(1) adenosine receptor signal and AMPK involving caspase-9/-3 activation are responsible for adenosine-induced RCR-1 astrocytoma cell death. Neurotoxicology (2006) 27:458-67. doi:10.1016/j.neuro.2005.12.008

196. Barry CP, Lind SE. Adenosine-mediated killing of cultured epithelial cancer cells. Cancer Res (2000) 60:1887-94.

197. De ME, Orioli E, Dal BD, Adinolfi E. P2X7 receptor as a therapeutic target. Adv Protein Chem Struct Biol (2016) 104:39-79. doi:10.1016/bs.apcsb.2015. 11.004

198. Shabbir M, Thompson C, Jarmulowiczc M, Mikhailidis D, Burnstock G. Effect of extracellular ATP on the growth of hormone-refractory prostate cancer in vivo. BJU Int (2008) 102:108-12. doi:10.1111/j.1464-410X.2008. 07578.x

199. White N, Knight GE, Butler PE, Burnstock G. An in vivo model of melanoma: treatment with ATP. Purinergic Signal (2009) 5:327-33. doi:10.1007/ s11302-009-9156-0

200. Agteresch HJ, Burgers SA, van der Gaast A, Wilson JH, Dagnelie PC. Randomized clinical trial of adenosine 5'-triphosphate on tumor growth and survival in advanced lung cancer patients. Anticancer Drugs (2003) 14:639-44. doi:10.1097/00001813-200309000-00009

201. Beijer S, Hupperets PS, van den Borne BE, Eussen SR, van Henten AM, van den Beuken-van Everdingen M, et al. Effect of adenosine 5'-triphosphate infusions on the nutritional status and survival of preterminal cancer patients. Anticancer Drugs (2009) 20:625-33. doi:10.1097/CAD.0b013e32832d4f22

202. Beijer S, Hupperets PS, van den Borne BE, Wijckmans NE, Spreeuwenberg C, van den Brandt PA, et al. Randomized clinical trial on the effects of adenosine 5 '-triphosphate infusions on quality of life, functional status, and fatigue in preterminal cancer patients. J Pain Symptom Manage (2010) 40:520-30. doi:10.1016/j.jpainsymman.2010.01.023

203. Fu W, McCormick T, Qi X, Luo L, Zhou L, Li X, et al. Activation of P2X(7)-mediated apoptosis inhibits DMBA/TPA-induced formation of skin papillomas and cancer in mice. BMC Cancer (2009) 9:114. doi:10.1186/1471-2407-9-114

204. Zhou JZ, Riquelme MA, Gao X, Ellies LG, Sun LZ, Jiang JX. Differential impact of adenosine nucleotides released by osteocytes on breast cancer growth and bone metastasis. Oncogene (2015) 34:1831-42. doi:10.1038/ onc.2014.113

205. Gehring MP, Pereira TC, Zanin RF, Borges MC, Braga Filho A, Battastini AM, et al. $\mathrm{P} 2 \mathrm{X} 7$ receptor activation leads to increased cell death in a radiosensitive human glioma cell line. Purinergic Signal (2012) 8:729-39. doi:10.1007/ s11302-012-9319-2

206. Fucikova J, Moserova I, Urbanova L, Bezu L, Kepp O, Cremer I, et al. Prognostic and predictive value of DAMPs and DAMP-associated processes in cancer. Front Immunol (2015) 6:402. doi:10.3389/fimmu.2015.00402

207. Pol J, Vacchelli E, Aranda F, Castoldi F, Eggermont A, Cremer I, et al. Trial watch: immunogenic cell death inducers for anticancer chemotherapy. Oncoimmunology (2015) 4:e1008866. doi:10.1080/2162402X.2015.1008866

208. Gehring MP, Kipper F, Nicoletti NF, Sperotto ND, Zanin R, Tamajusuku AS, et al. P2X7 receptor as predictor gene for glioma radiosensitivity and median survival. Int J Biochem Cell Biol (2015) 68:92-100. doi:10.1016/j. biocel.2015.09.001

209. de Andrade Mello P, Bian S, Savio LEB, Zhang H, Zhang J, Junger W, et al. Hyperthermia and associated changes in membrane fluidity potentiate P2X7 activation to promote tumor cell death. Oncotarget (2017) 8:67254-68. doi:10.18632/oncotarget.18595

210. Vázquez-Cuevas FG, Martínez-Ramírez AS, Robles-Martínez L, Garay E, García-Carrancá A, Pérez-Montiel D, et al. Paracrine stimulation of P2X7 receptor by ATP activates a proliferative pathway in ovarian carcinoma cells. J Cell Biochem (2014) 115:1955-66. doi:10.1002/jcb.24867 
211. Ryu JK, Jantaratnotai N, Serrano-Perez MC, McGeer PL, McLarnon JG. Block of purinergic P2X7R inhibits tumor growth in a C6 glioma brain tumor animal model. J Neuropathol Exp Neurol (2011) 70:13-22. doi:10.1097/ NEN.0b013e318201d4d4

212. Hattori M, Gouaux E. Molecular mechanism of ATP binding and ion channel activation in P2X receptors. Nature (2012) 485:207-12. doi:10.1038/ nature11010

213. Gilbert SM, Gidley Baird A, Glazer S, Barden JA, Glazer A, Teh LC, et al. A phase I clinical trial demonstrates that nfP2X7-targeted antibodies provide a novel, safe and tolerable topical therapy for basal cell carcinoma. $\mathrm{Br}$ J Dermatol (2017) 177:117-24. doi:10.1111/bjd.15364

214. CappellariAR, Rockenbach L, Dietrich F, Clarimundo V, Glaser T, BraganholE, et al. Characterization of ectonucleotidases in human medulloblastoma cell lines: ecto-5'NT/CD73 in metastasis as potential prognostic factor. PLoS One (2012) 7:e47468. doi:10.1371/journal.pone.0047468

215. Hayes GM, Cairns B, Levashova Z, Chinn L, Perez M, Theunissen JW, et al. CD39 is a promising therapeutic antibody target for the treatment of soft tissue sarcoma. Am J Transl Res (2015) 7:1181-8.

216. Cai XY, Wang XF, Li J, Dong JN, Liu JQ, Li NP, et al. High expression of CD39 in gastric cancer reduces patient outcome following radical resection. Oncol Lett (2016) 12:4080-6. doi:10.3892/ol.2016.5189

217. Künzli BM, Berberat PO, Giese T, Csizmadia E, Kaczmarek E, Baker C, et al. Upregulation of CD39/NTPDases and P2 receptors in human pancreatic disease. Am J Physiol Gastrointest Liver Physiol (2007) 292:G223-30. doi:10.1152/ajpgi.00259.2006

218. Künzli BM, Bernlochner MI, Rath S, Käser S, Csizmadia E, Enjyoji K, et al. Impact of CD39 and purinergic signalling on the growth and metastasis of colorectal cancer. Purinergic Signal (2011) 7:231-41. doi:10.1007/ s11302-011-9228-9

219. Zhang B, Cheng B, Li FS, Ding JH, Feng YY, Zhuo GZ, et al. High expression of CD39/ENTPD1 in malignant epithelial cells of human rectal adenocarcinoma. Tumour Biol (2015) 36:9411-9. doi:10.1007/s13277-015-3683-9

220. Aliagas E, Vidal A, Texido L, Ponce J, Condom E, Martin-Satue M. High expression of ecto-nucleotidases CD39 and CD73 in human endometrial tumors. Mediators Inflamm (2014) 2014:509027. doi:10.1155/2014/509027

221. Montalban Del Barrio I, Penski C, Schlahsa L, Stein RG, Diessner J, Wöckel A, et al. Adenosine-generating ovarian cancer cells attract myeloid cells which differentiate into adenosine-generating tumor associated macrophages - a self-amplifying. J Immunother Cancer (2016) 4:49. doi:10.1186/ s40425-016-0154-9

222. Pulte D, Furman RR, Broekman MJ, Drosopoulos JH, Ballard HS, Olson KE, et al. CD39 expression on T lymphocytes correlates with severity of disease in patients with chronic lymphocytic leukemia. Clin Lymphoma Myeloma Leuk (2011) 11:367-72. doi:10.1016/j.clml.2011.06.005

223. Perry C, Hazan-Halevy I, Kay S, Cipok M, Grisaru D, Deutsch V, et al. Increased CD39 expression on CD4(+) T lymphocytes has clinical and prognostic significance in chronic lymphocytic leukemia. Ann Hematol (2012) 91:1271-9. doi:10.1007/s00277-012-1425-2

224. Hilchey SP, Kobie JJ, Cochran MR, Secor-Socha S, Wang JC, Hyrien O, et al. Human follicular lymphoma CD39+-infiltrating $\mathrm{T}$ cells contribute to adenosine-mediated T cell hyporesponsiveness. J Immunol (2009) 183: 6157-66. doi:10.4049/jimmunol.0900475

225. Feng L, Sun X, Csizmadia E, Han L, Bian S, Murakami T, et al. Vascular CD39/ENTPD1 directly promotes tumor cell growth by scavenging extracellular adenosine triphosphate. Neoplasia (2011) 13:206-16. doi:10.1593/ neo. 101332

226. Sun X, Wu Y, Gao W, Enjyoji K, Csizmadia E, Müller CE, et al. CD39/ ENTPD1 expression by CD4+Foxp3+ regulatory T cells promotes hepatic metastatic tumor growth in mice. Gastroenterology (2010) 139:1030-40. doi:10.1053/j.gastro.2010.05.007

227. Jackson SW, Hoshi T, Wu Y, Sun X, Enjyoji K, Cszimadia E, et al. Disordered purinergic signaling inhibits pathological angiogenesis in cd39/Entpd1-null mice. Am J Pathol (2007) 171:1395-404. doi:10.2353/ajpath.2007.070190

228. Bastid J, Regairaz A, Bonnefoy N, Déjou C, Giustiniani J, Laheurte C, et al. Inhibition of CD39 enzymatic function at the surface of tumor cells alleviates their immunosuppressive activity. Cancer Immunol Res (2015) 3:254-65. doi:10.1158/2326-6066.CIR-14-0018

229. FigueiróF, de Oliveira CP,Bergamin LS, RockenbachL, MendesFB, JandreyEH, et al. Methotrexate up-regulates ecto-5'-nucleotidase/CD73 and reduces the frequency of $\mathrm{T}$ lymphocytes in the glioblastoma microenvironment. Purinergic Signal (2016) 12:303-12. doi:10.1007/s11302-016-9505-8

230. Bavaresco L, Bernardi A, Braganhol E, Cappellari AR, Rockenbach L, Farias PF, et al. The role of ecto-5'-nucleotidase/CD73 in glioma cell line proliferation. Mol Cell Biochem (2008) 319:61-8. doi:10.1007/s11010008-9877-3

231. Xu S, Shao QQ, Sun JT, Yang N, Xie Q, Wang DH, et al. Synergy between the ectoenzymes CD39 and CD73 contributes to adenosinergic immunosuppression in human malignant gliomas. Neuro Oncol (2013) 15:1160-72. doi:10.1093/neuonc/not067

232. Sadej R, Spychala J, Skladanowski AC. Expression of ecto-5'-nucleotidase (eN, CD73) in cell lines from various stages of human melanoma. Melanoma Res (2006) 16:213-22. doi:10.1097/01.cmr.0000215030.69823.11

233. Kondo T, Nakazawa T, Murata SI, Katoh R. Expression of CD73 and its ecto-5'-nucleotidase activity are elevated in papillary thyroid carcinomas. Histopathology (2006) 48:612-4. doi:10.1111/j.1365-2559.2005.02277.x

234. Kruger KH, Thompson LF, Kaufmann M, Moller P. Expression of ecto-5'nucleotidase (CD73) in normal mammary gland and in breast carcinoma. Br J Cancer (1991) 63:114-8. doi:10.1038/bjc.1991.23

235. Zhou X, Zhi X, Zhou P, Chen S, Zhao F, Shao Z, et al. Effects of ecto-5'nucleotidase on human breast cancer cell growth in vitro and in vivo. Oncol Rep (2007) 17:1341-6. doi:10.3892/or.17.6.1341

236. Wang L, Zhou X, Zhou T, Ma D, Chen S, Zhi X, et al. Ecto-5'-nucleotidase promotes invasion, migration and adhesion of human breast cancer cells. J Cancer Res Clin Oncol (2008) 134:365-72. doi:10.1007/s00432-007-0292-Z

237. Zhi X, Wang Y, Yu J, Yu J, Zhang L, Yin L, et al. Potential prognostic biomarker CD73 regulates epidermal growth factor receptor expression in human breast cancer. IUBMB Life (2012) 64:911-20. doi:10.1002/iub.1086

238. Goubran HA, Kotb RR, Stakiw J, Emara ME, Burnouf T. Regulation of tumor growth and metastasis: the role of tumor microenvironment. Cancer Growth Metastasis (2014) 7:9-18. doi:10.4137/CGM.S11285

239. Haun RS, Quick CM, Siegel ER, Raju I, Mackintosh SG, Tackett AJ. Bioorthogonal labeling cell-surface proteins expressed in pancreatic cancer cells to identify potential diagnostic/therapeutic biomarkers. Cancer Biol Ther (2015) 16:1557-65. doi:10.1080/15384047.2015.1071740

240. Wu XR, He XS, Chen YF, Yuan RX, Zeng Y, Lian L, et al. High expression of CD73 as a poor prognostic biomarker in human colorectal cancer. J Surg Oncol (2012) 106:130-7. doi:10.1002/jso.23056

241. Stella J, Bavaresco L, Braganhol E, Rockenbach L, Farias PF, Wink MR, et al. Differential ectonucleotidase expression in human bladder cancer cell lines. Urol Oncol (2010) 28:260-7. doi:10.1016/j.urolonc.2009.01.035

242. Rockenbach L, Braganhol E, Dietrich F, Figueiró F, Pugliese M, Edelweiss MI, et al. NTPDase3 and ecto-5'-nucleotidase/CD73 are differentially expressed during mouse bladder cancer progression. Purinergic Signal (2014) 10:421-30. doi:10.1007/s11302-014-9405-8

243. Oh HK, Sin JI, Choi J, Park SH, Lee TS, Choi YS. Overexpression of CD73 in epithelial ovarian carcinoma is associated with better prognosis, lower stage, better differentiation and lower regulatory T cell infiltration. J Gynecol Oncol (2012) 23:274-81. doi:10.3802/jgo.2012.23.4.274

244. Yang Q, Du J, Zu L. Overexpression of CD73 in prostate cancer is associated with lymph node metastasis. Pathol Oncol Res (2013) 19:811-4. doi:10.1007/ s12253-013-9648-7

245. Stagg J, Divisekera U, Duret H, Sparwasser T, Teng MW, Darcy PK, et al. CD73-deficient mice have increased antitumor immunity and are resistant to experimental metastasis. Cancer Res (2011) 71:2892-900. doi:10.1158/00085472.CAN-10-4246

246. Yegutkin GG, Marttila-Ichihara F, Karikoski M, Niemelä J, Laurila JP, Elima K, et al. Altered purinergic signaling in CD73-deficient mice inhibits tumor progression. Eur J Immunol (2011) 41:1231-41. doi:10.1002/eji.201041292

247. Stagg J, Beavis PA, Divisekera U, Liu MC, Möller A, Darcy PK, et al. CD73deficient mice are resistant to carcinogenesis. Cancer Res (2012) 72:2190-6. doi:10.1158/0008-5472.CAN-12-0420

248. Forte G, Sorrentino R, Montinaro A, Luciano A, Adcock IM, Maiolino P et al. Inhibition of CD73 improves B cell-mediated anti-tumor immunity in a mouse model of melanoma. J Immunol (2012) 189:2226-33. doi:10.4049/ jimmunol.1200744

249. Stagg J, Divisekera U, McLaughlin N, Sharkey J, Pommey S, Denoyer D, et al. Anti-CD73 antibody therapy inhibits breast tumor growth and metastasis. Proc Natl Acad Sci U S A (2010) 107:1547-52. doi:10.1073/pnas.0908801107 
250. Rust S, Guillard S, Sachsenmeier K, Hay C, Davidson M, Karlsson A, et al. Combining phenotypic and proteomic approaches to identify membrane targets in a 'triple negative' breast cancer cell type. Mol Cancer (2013) 12:11. doi:10.1186/1476-4598-12-11

251. Zhi X, Wang Y, Zhou X, Yu J, Jian R, Tang S, et al. RNAi-mediated CD73 suppression induces apoptosis and cell-cycle arrest in human breast cancer cells. Cancer Sci (2010) 101:2561-9. doi:10.1111/j.1349-7006.2010. 01733.x

252. Geoghegan JC, Diedrich G, Lu X, Rosenthal K, Sachsenmeier KF, Wu H, et al. Inhibition of CD73 AMP hydrolysis by a therapeutic antibody with a dual, non-competitive mechanism of action. MAbs (2016) 8:454-67. doi:10.1080/ 19420862.2016.1143182

253. Hay CM, Sult E, Huang Q, Mulgrew K, Fuhrmann SR, McGlinchey KA, et al. Targeting CD73 in the tumor microenvironment with MEDI9447. Oncoimmunology (2016) 5:e1208875. doi:10.1080/2162402X.2016.1208875

254. Loi S, Pommey S, Haibe-Kains B, Beavis PA, Darcy PK, Smyth MJ, et al. CD73 promotes anthracycline resistance and poor prognosis in triple negative breast cancer. Proc Natl Acad Sci U S A (2013) 110:11091-6. doi:10.1073/ pnas. 1222251110

255. Allard B, Pommey S, Smyth MJ, Stagg J. Targeting CD73 enhances the antitumor activity of anti-PD-1 and anti-CTLA-4 mAbs. Clin Cancer Res (2013) 19:5626-35. doi:10.1158/1078-0432.CCR-13-0545

256. Iannone R, Miele L, Maiolino P, Pinto A, Morello S. Adenosine limits the therapeutic effectiveness of anti-CTLA4 $\mathrm{mAb}$ in a mouse melanoma model. Am J Cancer Res (2014) 4:172-81.
257. Beavis PA, Milenkovski N, Henderson MA, John LB, Allard B, Loi S, et al. Adenosine receptor 2A blockade increases the efficacy of anti-PD-1 through enhanced antitumor T-cell responses. Cancer Immunol Res (2015) 3:506-17. doi:10.1158/2326-6066.CIR-14-0211

258. Waickman AT, Alme A, Senaldi L, Zarek PE, Horton M, Powell JD. Enhancement of tumor immunotherapy by deletion of the A2A adenosine receptor. Cancer Immunol Immunother (2012) 61:917-26. doi:10.1007/ s00262-011-1155-7

259. Mittal D, Young A, Stannard K, Yong M, Teng MW, Allard B, et al. Antimetastatic effects of blocking PD-1 and the adenosine A2A receptor. Cancer Res (2014) 74:3652-8. doi:10.1158/0008-5472.CAN-14-0957

260. Young A, Ngiow SF, Barkauskas DS, Sult E, Hay C, Blake SJ, et al. Co-inhibition of CD73 and A2AR adenosine signaling improves anti-tumor immune responses. Cancer Cell (2016) 30:391-403. doi:10.1016/j.ccell.2016.06.025

Conflict of Interest Statement: The authors declare that the research was conducted in the absence of any commercial or financial relationships that could be construed as a potential conflict of interest.

Copyright (c) 2017 de Andrade Mello, Coutinho-Silva and Savio. This is an openaccess article distributed under the terms of the Creative Commons Attribution License (CC BY). The use, distribution or reproduction in other forums is permitted, provided the original author(s) or licensor are credited and that the original publication in this journal is cited, in accordance with accepted academic practice. No use, distribution or reproduction is permitted which does not comply with these terms. 